\title{
Single stage, late Archaean exhumation of granulites in the Northern Marginal Zone, Limpopo Belt, Zimbabwe, and relevance to gold mineralization at Renco mine
}

\author{
Tom G. Blenkinsop \\ Department of Geology, University of Zimbabwe, P.O. Box MP 167, Mount Pleasant, Harare, Zimbabwe \\ Present Address: School of Earth Sciences, James Cook University, \\ Townsville, Queensland QLD 4811 Australia, \\ e-mail: Thomas.Blenkinsop@jcu.edu.au
}

\author{
A. Kröner \\ Department of Geology, University Mainz, Mainz, Germany \\ e-mail: kroener@mail.uni-mainz.de

\section{Chiwara} \\ Rio Tinto, Zimbabwe, PO Box AY 266, Harare, Zimbabwe \\ e-mail: Victor.Chiwara@riotinto.com
}

(c) 2004 Geological Society of South Africa

\begin{abstract}
Detailed field mapping and geochronological studies in the Renco mine area of the Northern Marginal Zone of the Limpopo Belt allow two distinct tectonic events to be distinguished in the late Archaean to Palaeoproterozoic. In the first event, granulite-facies metamorphism ( $\sim 2720$ to $\sim 2590 \mathrm{Ma}$ ) was followed by the formation of pervasive steep fabrics accommodating north-northwest shortening, and a network of amphibolite-facies shear zones. Enderbitic rocks were intruded over the interval $\sim 2739$ to $\sim 2571 \mathrm{Ma}$, and granites were intruded over a largely overlapping period of $\sim 2654$ to $\sim 2517 \mathrm{Ma}$. The intrusion of syn-tectonic granites $(\sim 2600$ to $\sim 2500 \mathrm{Ma}$ ) allows the convergent tectonics to be dated as late Archaean. The second event produced deformation zones dominated by cataclasis at maximum temperatures of $400^{\circ} \mathrm{C}$, and may have involved localized pseudotachylite generation. These deformation zones have maximum lengths and widths of several hundred metres and $2 \mathrm{~m}$ respectively: they are separated along and across strike by several kilometres, and did not accommodate significant crustal displacement. They probably formed in the second event at $\sim 2000 \mathrm{Ma}$. The granulites were therefore exhumed in the first event, following directly on granulite-facies metamorphism, implying that a substantial crustal thickness was attained in the late Archaean. Amphibolite facies gold mineralization at Renco mine probably occurred at this time, followed by Palaeoproterozoic remobilization.
\end{abstract}

\section{Introduction}

Granulites that form in the lower plate of an orogen, or those that form in single plate crust, can not be exhumed as a result of isostatic forces during a single orogeny (Ellis, 1987). Their occurrence at the Earth's surface requires a second orogenic cycle, and their cooling at depth should result in the preservation of only retrograde reactions. High-temperature, low-pressure granulites are a special class of granulites formed by high geothermal gradients that can originate in crust less than the critical thickness for single stage exhumation. Several cases of granulites that have been exhumed in two stages have been given by Ellis (1987), and granulites of the Northern Marginal Zone (NMZ) of the Limpopo belt in southern Africa have been cited as an example by Kamber et al. (1996).

Recent geochronological studies of the Limpopo belt, mainly focused on the Central Zone, have demonstrated the importance of a major tectonothermal event at $\sim 2.0$ Ga (e.g. Kamber et al., 1992; 1995a; 1996; Barton et al., 1994, Jaeckel et al., 1997; Holzer et al., 1996; 1998;
1999). Kamber et al. (1996) suggested that thrusting of the NMZ over the Zimbabwe Craton and granulite exhumation occurred during this Palaeoproterozoic event at $\sim 1.97 \mathrm{Ga}$, subsequent to Archaean thrusting. This would appear to agree with requirements of the Ellis (1987) model for granulites that formed in single plate crust. An integral part of this suggestion is that the Archaean crust in the NMZ was never very thick. In contradiction to this scenario, it has been suggested that no measurable Proterozoic thrusting and granulite exhumation has occurred in the northern part of the NMZ (Blenkinsop and Mkweli, 1995; Mkweli, 1998) because satellites of the Great Dyke do not show any measurable displacement across the NMZ/Zimbabwe Craton boundary.

The second largest producing gold mine in Zimbabwe is located within the NMZ at Renco (annual gold production around 1 tonne). The Archaean/ Palaeoproterozoic tectonics of the NMZ are of special economic interest because of controversy over the timing and conditions of this major gold deposit. 


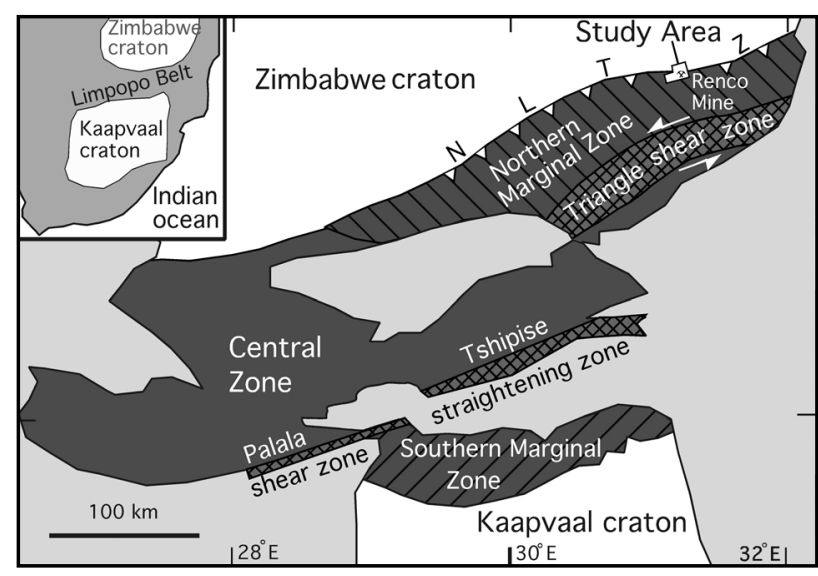

Figure 1. Simplified sketch map of the Northern Marginal Zone, after Holzer et al. (1998). Inset shows Limpopo Belt between the Kaapvaal and Zimbabwe Cratons.

Blenkinsop and Frei (1996) have argued for at least two stages of mineralization in the Palaeoproterozoic at $<\sim 2.4 \mathrm{Ga}$ and at $\sim 1.9 \mathrm{Ga}$, whereas Kisters et al. (1997; 1998; 2000) and Kolb et al. (2000; 2003) maintain that mineralization was related to late Archaean tectonics. The structural geology of the area around Renco is of crucial importance to the resolution of this debate.

The major aim is of this study is to document and evaluate the evidence for Archaean and Palaeoproterozoic tectonics in part of the northern NMZ with respect to granulite formation and exhumation, emphasizing field relationships by detailed mapping. A secondary aim is to contribute to the debate on the nature and timing of gold mineralization at Renco mine in the light of the tectonic results. The results call into question the suggestion of two-stage granulite exhumation in this part of the Limpopo belt.

\section{Regional geological background The Limpopo belt}

The Limpopo belt is situated between the Archaean Kaapvaal and Zimbabwe Cratons to the south and north respectively (Figure 1, inset) and is made up of three distinct domains separated from each other by major shear zones. These domains are the Northern Marginal Zone (NMZ), the Southern Marginal Zone (SMZ) and the Central Zone (CZ) (Cox et al. 1965; Figure 1). Both the Marginal Zones have major components of tonalitictrondhjemitic-granodioritic igneous assemblages and their metamorphic derivatives, with intercalated supracrustal rocks resembling lithologies occurring in greenstone belts of the adjacent cratons (Rollinson and Blenkinsop, 1995). These two domains have therefore been regarded as deformed segments of Archaean granite greenstone terrains (for summaries and older literature see Van Reenen et al., 1992; Rollinson, 1993). In contrast, the $\mathrm{CZ}$ is lithologically markedly different and contains abundant granodioritic to granitic gneisses with subordinate tonalites and trondhjemites, that are tectonically interlayered with clastic and chemical metasediments, suggesting stable depositional environments, and minor mafic metavolcanics (see papers in Van Biljon and Legg, 1983; van Reenen et al., 1992). The southern margin of the SMZ is defined as the Palala Shear Zone and the Tshipise Straightening Zone, whereas the boundary between the $\mathrm{CZ}$ and the NMZ is known as the Triangle Shear Zone (James, 1975; McCourt and Vearncombe, 1987; 1992; Brandl and Reimold, 1990; Holzer et al. 1998; Schaller et al., 1999; see Figure 1).

A multiplicity of Archaean and Palaeoproterozoic magmatic and metamorphic events in the CZ has been documented by Jaeckel et al. (1997) and Kröner et al. (1998; 1999). Late Archaean tectonometamorphism is well known from the SMZ and NMZ (e.g. van Reenen et al., 1992; Barton and Van Reenen, 1992; Berger et al., 1995). Sm-Nd Garnet ages of $\sim 2.0$ Ga from the Triangle Shear Zone were published by Van Breenen and Hawkesworth (1980) and subsequently confirmed by Kamber et al. (1995a), and in the southern part of the NMZ (the Transition Zone) by Kamber et al. (1995b). The evidence for Palaeoproterozoic deformation in the northern part of the NMZ, where this study is located, comes from $\mathrm{Pb}-\mathrm{Pb}$ step leaching ages on titanites together with biotite and epidote in shear zones in the NMZ, which gave results of $1959 \pm 17$ and $1971 \pm 11 \mathrm{Ma}$, and from Ar-Ar ages on amphiboles and biotite, which give the same ages within error, or older results that are interpreted as partial resetting of Archaean amphiboles at $\sim 1.97 \mathrm{Ga}$ (Kamber et al., 1996). The Palaeoproterozoic event is considered to be at minimum and maximum temperatures of $420^{\circ} \mathrm{C}$ and $500^{\circ} \mathrm{C}$ on the basis of new garnet growth in metapelite and brittle deformation of feldspar respectively, and to have occurred between $\sim 1.96$ and $\sim 1.98$ Ga (Kamber et al., 1996).

\section{Petrography and field relationships General}

By far the majority of rocks in the field area were originally intrusive in nature and have been described as the Plutonic Assemblage by Rollinson and Blenkinsop (1995), including mafic granulites, felsic gneisses, and enderbites. The only representation of the Supracrustal Assemblage of Rollinson and Blenkinsop (1995) comprises loose boulders of iron formation. The Plutonic and Supracrustal Assemblages were intruded by dolerite dykes. The following descriptions are given in approximate chronological order of petrogenesis, and the disposition of the rocks is shown on Figure 2 . Excellent exposure occurs on the numerous hills throughout the area, and good exposures occur in stream and river beds.

\section{Banded Iron Formation}

Banded iron formation is found as isolated float in three small areas. Individual boulders show tight, $\mathrm{cm}$-scale folds of the banding. The banded iron formation consists of magnetite and quartz. 


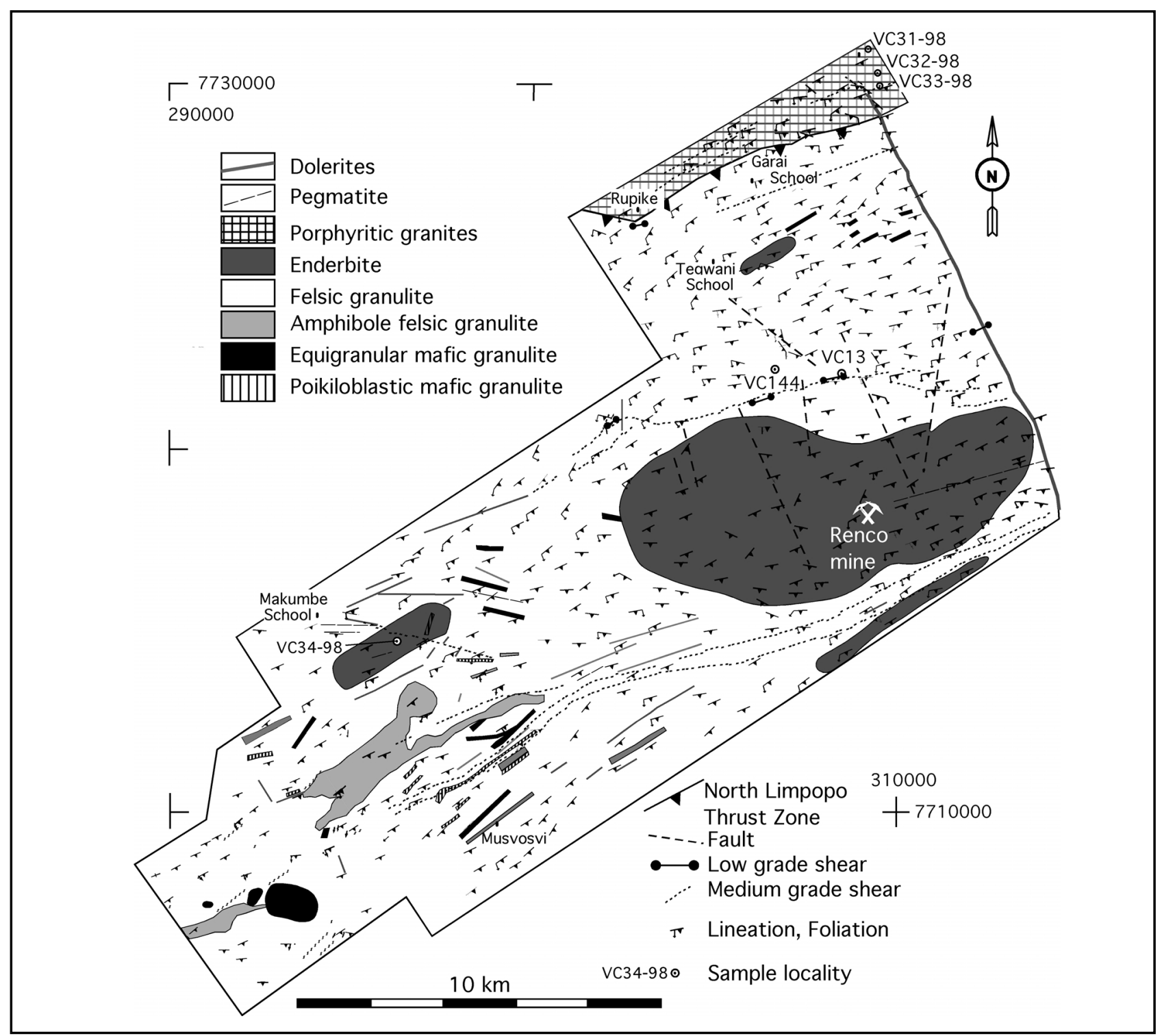

Figure 2. Detailed geological map of the study area. The prominent thrust symbol in the Northern part of the map is the North Limpopo Thrust Zone. The grid points are in UTM coordinates.

\section{Mafic granulites}

There are two sorts of mafic granulite in the area, distinguished by the absence/presence of orthopyroxene poikiloblasts in the assemblage orthopyroxeneplagioclase-biotite-hornblende-opaques-quartz.

\section{Equigranular mafic granulite.}

Typically this rock occurs as narrow elongate bodies with dimensions 10 to $20 \mathrm{~m}$ wide and $200 \mathrm{~m}$ long within granulite gneisses (Figure 2). There is little mineralogical variation apart from weak $\mathrm{cm}$-scale banding due to variable proportions of plagioclase. Hornblende occurs as 1 to $2 \mathrm{~mm}$ crystals with orthopyroxene and plagioclase symplectites on grain boundary edges (Figure 3a). These symplectites show a prograde reaction that can be represented as:

Hornblende + Quartz $\rightarrow$ Plagioclase + Orthopyroxene + $\mathrm{H}_{2} \mathrm{O}$
Biotite ( 1 to $2 \mathrm{~mm}$ grains) is preferentially aligned in micro-shear zones $0.3 \mathrm{~mm}$ wide that define a penetrative fabric. Two generations of biotite exist. The first generation is green-brown and defines the regional fabric. The second generation is red-brown and occurs as an alteration product from the reaction:

Orthopyroxene + Hornblende + Plagioclase + Fluid $\rightarrow$ Biotite

\section{2}

The above hydration reaction occurs in zones that imply K-metasomatism (Kamber and Biino, 1995). The reaction represents retrograde metamorphism in lower amphibolite facies to upper greenschist facies after granulite facies conditions.

An elliptical body of massive mafic granulite occurs in the western portion of the study area with dimensions $500 \mathrm{~m}$ by $600 \mathrm{~m}$ (Figure 2). These rocks have an equigranular texture of 2 to $3 \mathrm{~mm}$ grains of ortho- 

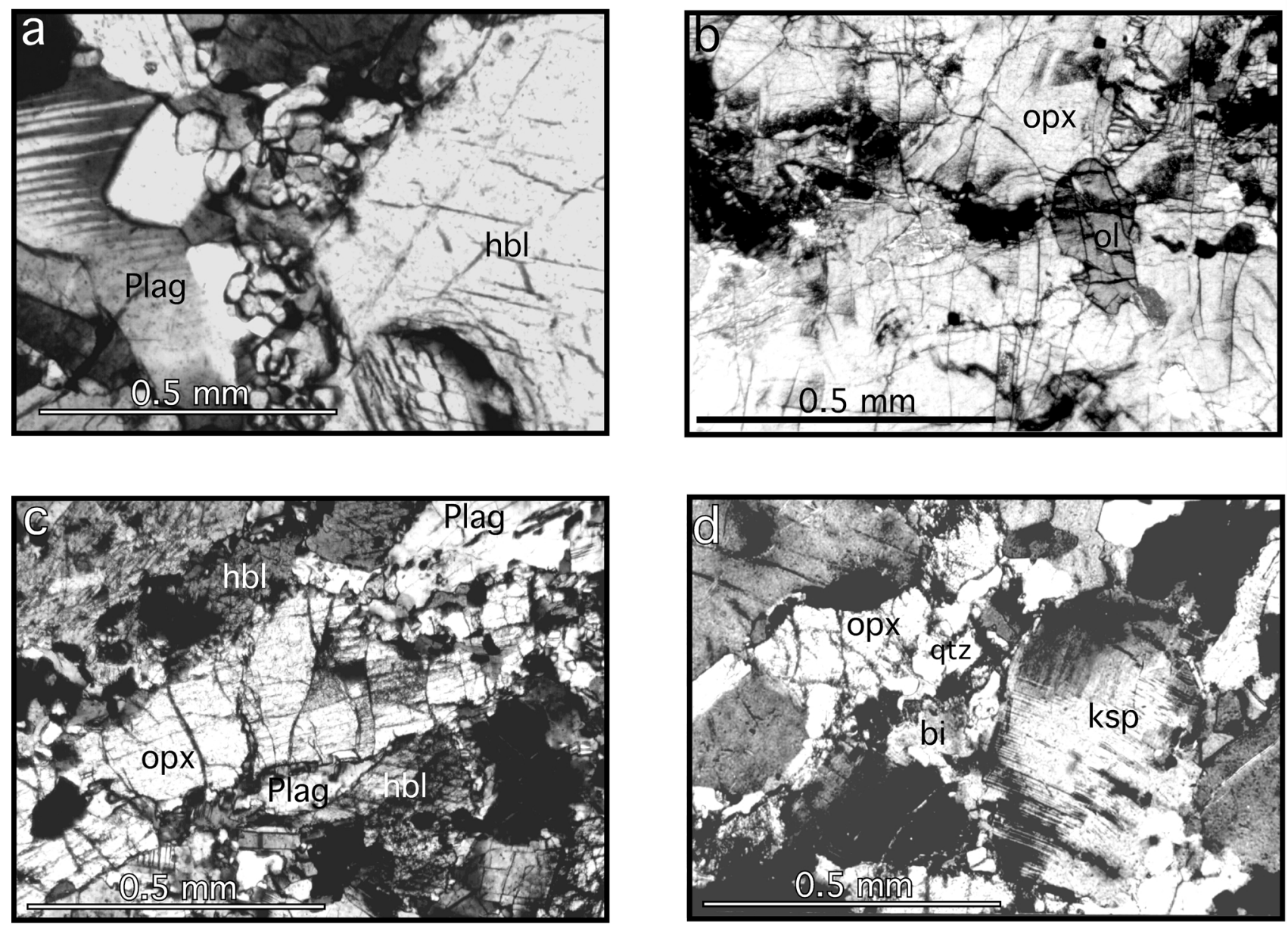

Figure 3. Microstructures of mafic and felsic granulites and enderbites. (a) Orthopyroxene-plagioclase symplectites between hornblende (hbl) and plagioclase (plag) in equigranular mafic granulite. Crossed polars. (b) Orthopyroxene poikiloblasts (opx) in poikilobalstic mafic granulites, with olivine inclusion (ol). Crossed polars. (c) Hornblende (hbl) and plagioclase (plag) replacing orthopyroxene (opx) in felsic granulite. (d) Quartz (qtz) and biotite (bi) between orthopyroxene (opx) and K-feldspar (ksp) in enderbites. Lack of delicate intergrowths between quartz and biotite suggest that this texture formed through hydration (reaction 4); see text.

pyroxene and hornblende in undeformed portions of the rock, and a weak alignment of mafic minerals elsewhere.

\section{Poikiloblastic mafic gramulite}

Poikiloblastic mafic granulite also occurs as elongate bodies trending east-northeast, 10 to 50m wide and 100's of meters long (Figure 2). It has a characteristic pimply surface due to orthopyroxene poikiloblasts. This surface texture distinguishes it in the field from equigranular mafic granulite. A foliation of aligned mafic minerals is seen on some loose boulders. It is difficult to establish whether foliation traces are parallel to the regional foliation or not, due to lack of outcrop. Orthopyroxene occurs as $2 \times 5 \mathrm{~mm}$ poikiloblasts, which contain olivine and clinopyroxene inclusions up to $0.8 \mathrm{~mm}$ in size (Figure 3b). Olivine occurs as small fractured crystals $0.5 \mathrm{~mm}$ in size. Fractures in the olivine are filled with retrograde serpentine and $0.1 \mathrm{~mm}$ quartz grains.

\section{Felsic gneisses}

Felsic gneisses contain the mineral assemblage of microperthitic microcline, quartz, plagioclase, biotite, \pm hornblende, pyroxene, garnet, and chlorite, with accessory magnetite, titanite, epidote and apatite. They are compositionally tonalitic to monzogranitic, and in terms of their chemical affinities, they are indistinguishable from some gneisses and granites of the Zimbabwe Craton (Berger et al., 1995). These light grey rocks range from banded on a $\mathrm{cm}$ scale to massive varieties. Microcline grains are 1 to $2 \mathrm{~mm}$ in size and often show considerable intracrystalline strain in the form of undulatory extinction and serrated grain boundaries. Sericite, quartz and biotite occur in pressure shadows around microcline porphyroclasts. Quartz is found as aggregates and ribbons of equant grains, approximately $0.15 \mathrm{~mm}$ in size, defining a planar fabric that wraps around feldspar porphyroclasts, and as larger porphyroclasts $(0.3 \mathrm{~mm})$ which also define the fabric. Quartz is generally strain-free, although some undulatory extinction as well as subgrains and grain boundary migration features are seen in the larger grains. Symplectic growths, $0.8 \mathrm{~mm}$ in size, of clinopyroxene and quartz occur between K-feldspar grains and orthopyroxene. Green and brown biotite define a planar fabric which wraps around 2 to $3 \mathrm{~mm}$ 

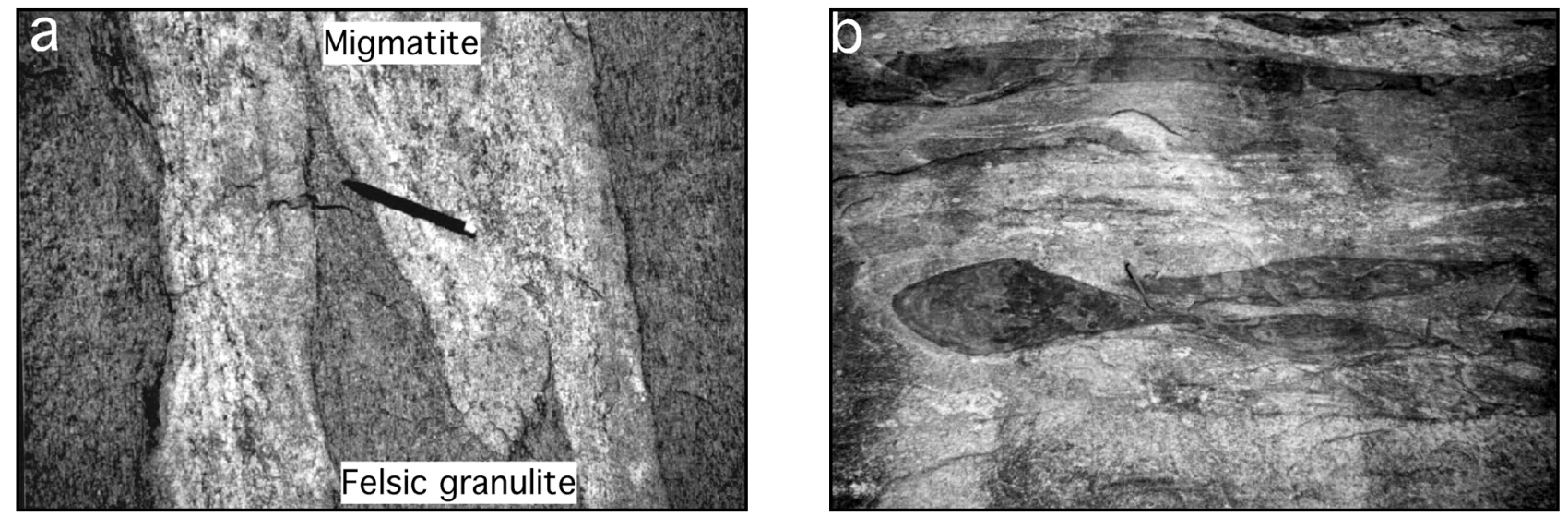

Figure 4. Field aspects of felsic granulites. (a) Migmatites ("white granite" of Rollinson and Blenkinsop 1995) in foliated felsic granulite. Pen for scale $\sim 10 \mathrm{~cm}$. (b) Deformed mafic xenoliths in foliated felsic granulite.

garnet porphyroclasts that are densely sliced by shear fractures and contain inclusions of quartz and biotite. Hornblende occurs as elongate to rounded crystals $0.6 \mathrm{~mm}$ in size which are altered to chlorite, quartz and biotite. Orthopyroxene occurs mostly in relict form as $0.4 \mathrm{~mm}$ grains. The edges of grains are altered to clinopyroxene, quartz, plagioclase and chlorite. A subtype of the felsic gneisses consists of a variety with a higher proportion of biotite. The plagioclase/K-feldspar ratio, and the proportion of mafic minerals decreases with increasing strain intensity (Ridley, 1992).

Migmatitic segregations (Figure 4a) show evidence of melting both early and late in the deformational history. Elongate xenoliths of mafic granulite up to $0.5 \mathrm{~m}$ in size occur in the felsic gneiss (Figure $4 \mathrm{~b}$ ). These xenoliths have rims up to a few $\mathrm{cm}$ thick of darker weathering, that are described as "dehydration rims" by Rollinson and Blenkinsop (1995) or "partial host-xenolith equilibriation" by Kamber and Biino (1995). These rims contain pyroxene considered to have formed when the xenoliths were intruded by water-undersaturated magma.

A distinctive coarse grained, dark grey felsic gneiss (amphibole felsic granulite, Figure 2) occurs in the southwest of the area, characterised by a greater hornblende content of typically 5\%. Centimetre-scale banding defined by alternating mafic and felsic layers may be tightly folded, and migmatization is widespread in places. K-feldspar occurs as $\mathrm{mm}$ porphyroclasts. Orthopyroxene grains of the same size may be rimmed by 0.2 to $0.4 \mathrm{~mm}$ hornblende, plagioclase and/or quartz (Figure 3c). Larger hornblende grains (0.7 to $1 \mathrm{~mm}$ ) occur where orthopyroxene has been completely replaced. Quartz occurs as $0.3 \mathrm{~mm}$ grains that form ribbons $0.5 \mathrm{~mm}$ wide, and as porphyroclasts. Plagioclase occurs as 0.6 to $0.8 \mathrm{~mm}$ subhedral grains, and garnet is present as 1 to $2 \mathrm{~mm}$ elongate grains associated with opaques, commonly replaced by epidote, chlorite and opaques.

\section{Enderbites}

Enderbites are orthopyroxene-bearing quartzofeldspathic granulites distinguished from charnockites by their higher plagioclase/orthoclase ratio, giving them tonalitic to granodioritic QAP compositions (e.g. Streckiesen 1976). Four enderbite intrusions occur in the area of study (Figure 2). The largest body, which hosts the gold mineralisation at Renco, has dimensions of $10 \times 3 \mathrm{~km}$ (Figure 2). Fresh enderbites exposed at the Tokwe Mukorsi dam site $(25 \mathrm{~km}$ west-southwest of Renco Mine) during blasting have a similar appearance to the main Renco body. Enderbites from the dam were sampled during this study for geochronology (samples VC140 and VC141). These rocks are medium grained,

Table 1. Contrasting interpretations of biotite-quartz textures in Enderbites.

\begin{tabular}{ll}
\hline $\begin{array}{l}\text { Evidence in favour of dehydration crystallisation } \\
\text { reaction } \mathbf{3} \text { (Ridley, 1992) }\end{array}$ & $\begin{array}{l}\text { Evidence for limited extent of dehydration } \\
\text { crystallisation (Kamber and Biino, 1995) }\end{array}$ \\
\hline $\begin{array}{l}\text { Biotite-quartz growth is not preferentially along } \\
\text { orthopyroxene-K-feldpsar boundaries }\end{array}$ & $\begin{array}{l}\text { Allowance has not been made for textures due } \\
\text { to migmatisation }\end{array}$ \\
\hline $\begin{array}{l}\text { Lack of evidence for resorption in K-feldspar. } \\
\text { The uniformity of development of the texture, because the } \\
\text { hydration reaction should have depended on } \\
\text { heterogeneous fluid ingress. }\end{array}$ & $\begin{array}{l}\text { The texture overgrew orthopyroxene in strongly } \\
\text { retrogressed rocks. }\end{array}$ \\
\hline $\begin{array}{l}\text { The quartz-biotite intergrowths are similar to myrmekites } \\
\text { produced by melt-present reactions, unlike simple retrogression. }\end{array}$ & Some samples entirely lack a hydrous phase. \\
\hline
\end{tabular}




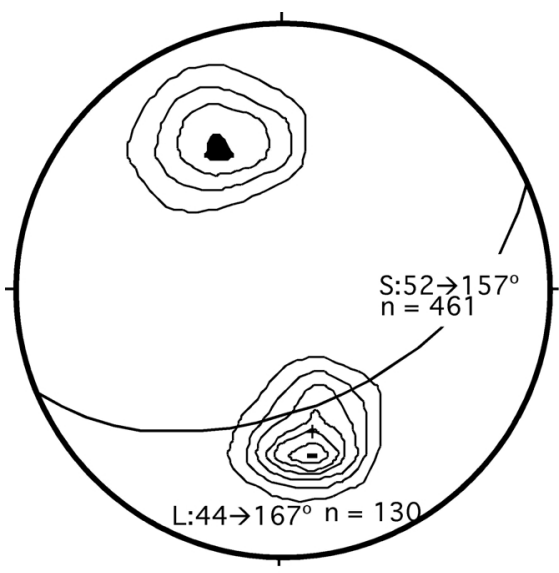

Felsic Granulites

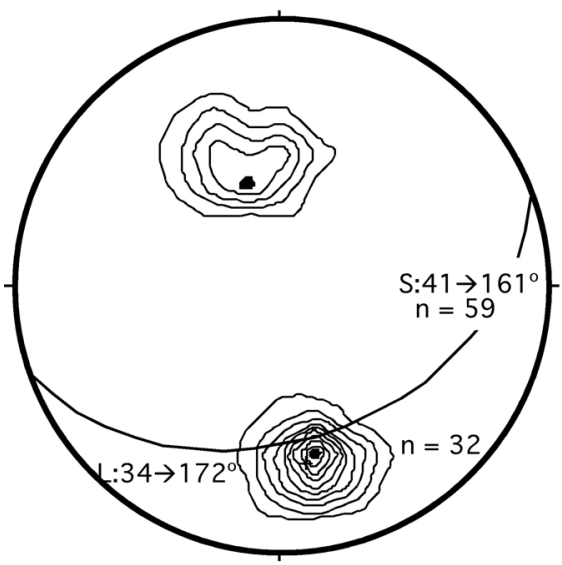

Porphyritic granites

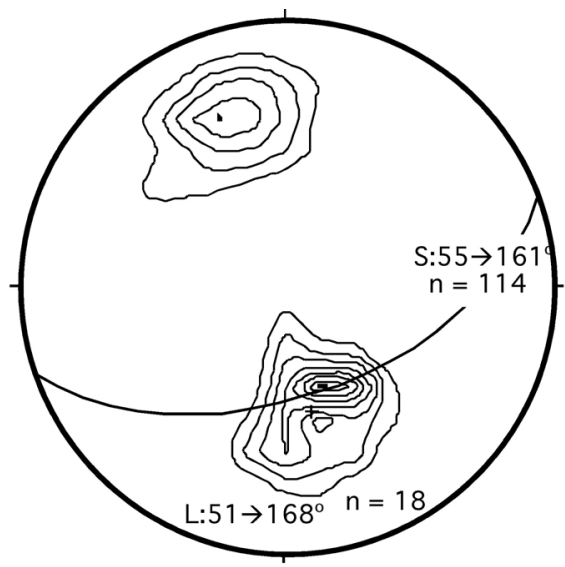

Enderbites

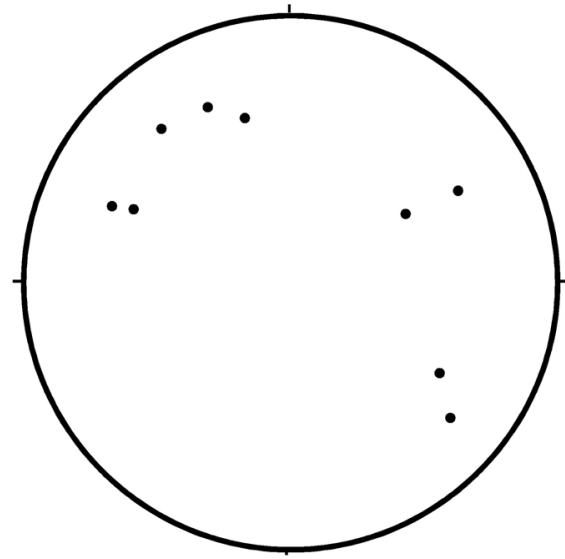

Mafic Granulites

Figure 5. Lower hemisphere, equal area projections of poles to foliations (S) and lineations (L) in the major rock type of the study area. Great circles are perpendicular to the maximum eigenvector of the poles to foliations (values gives dip to dip direction), and the maximum eigenvector of the lineations is shown by a bold cross (values give plunge to plunge bearing). $\mathrm{N}=$ number of measurements. Contours on the surface of the projection sphere; contour intervals in multiples of a uniform distribution starting from 1. Foliations dip to the southsoutheast, and lineations are down-dip, except in the mafic granulite.

grey-brown, and homogeneous; mostly they are massive but rarely they have a weak foliation. Quartz occurs as aggregates of grains $0.1 \mathrm{~mm}$ in size with undulatory extinction. Plagioclase (An46-62) is found as grains 0.6 to $0.8 \mathrm{~mm}$ in size. Orthopyroxene crystals are typically $0.8 \mathrm{~mm}$ in size and are rimmed by biotite and quartz (Figure 3d). The same textural relationships were described by Ridley (1992) and attributed to the water absent dehydration-crystallisation reaction:

Orthopyroxene + melt $->$ Biotite + quartz

Kamber and Biino (1995) found that this texture is relatively uncommon in the NMZ and interpreted most of the biotite interfingered with quartz as a retrogression texture, produced by the hydration reaction:

Orthopyroxene + K-feldspar + H2O -> Biotite + Quartz 4
A related possibility for the formation of this texture is the addition of $\mathrm{K}$ via a flux of late hydrous fluid. Evidence for the alternative explanations of the biotite quartz intergrowths is presented in Table 1.

The samples examined in this study support the origin of biotite and quartz in the enderbites both by the melt present reaction and retrogression, as observed by Kamber and Biino (1995). However, as comments on the above criteria, it can be pointed out that no samples lacking hydrous phases have been observed in this study area, and it is not clear why the existence of late magmatic quartz-plagioclase myrmekites should discount the existence of magmatic quartz-biotite intergrowths. Our observations suggest that best way to distinguish the two reactions is probably to examine the detailed textural relationships. Delicate intergrowths between biotite and quartz favour the melt present reaction (3), as per Ridleys' last point (Table 1), whereas retrogression creates more random quartz-biotite 


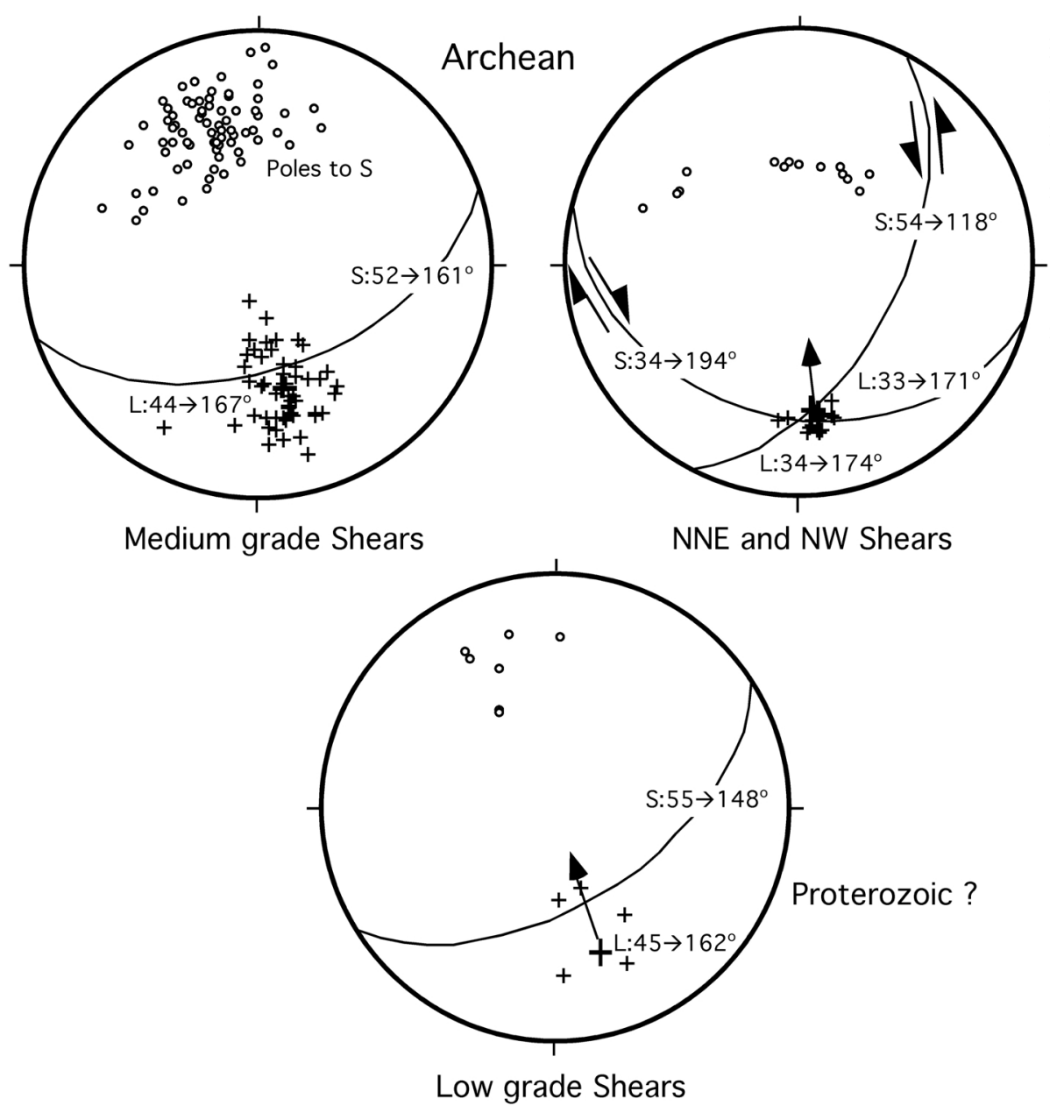

Figure 6. Lower hemisphere, equal area projections of poles to foliations (S) and lineations (L) in the shear zones of the study area. Conventions as in Figure 5. Medium grades shear dip to the south-southeast, with down-dip lineations, similar to the fabric in the Archeaen rocks shown in Figure 5 and interpreted to be Archeaen. Conjugate dextral and sinistral strike slip shears have a similar lineation, and the low grade shear have similar foliation and lineation orientations to the medium grade shears, but are interpreted to be Proterozoic.

relationships. The presence of the intergrowths without adjacent K-feldspar strongly supports the melt present reaction.

Hornblende is commonly rimmed by simplectites of orthopyroxene + plagioclase, seen as evidence for the prograde reaction (1). In melanocratic varieties of the enderbite, the proportion of mafic minerals increases by about $5 \%$.

\section{Porphyritic Granites}

Porphyritic granites occupy about $10 \%$ of the study area in the northeast, where they occur as elongate plutons along the North Limpopo Thrust Zone, in which they are highly deformed. Undeformed granites have a characteristic texture of subhedral, 1 to $4 \mathrm{~cm}$ long Kfeldspar megacrysts of microperthitic microcline that may be fractured and altered to chlorite and sericite. Recrystallized quartz grains are 0.1 to $0.3 \mathrm{~mm}$ in size. Subhedral plagioclase grains $0.5 \mathrm{~mm}$ in size have deformation twins. Orthopyroxene grains, $0.4 \mathrm{~mm}$ in size, are partly replaced by hornblende, chlorite and plagioclase. Shear domains are characterized by opaques, quartz ribbons, epidote, biotite and chlorite. Fine-grained bands of leucocratic porphyritic granites occur within coarser porphyritic granite.

\section{Pegmatites}

Granitic pegmatites, with a fabric parallel to the regional foliation, occur within felsic granulites. Within the porphyritic granites, similar pegmatites are either parallel to the general trend of foliation or crosscut these fabrics in the granites. Pegmatites in several orientations are folded within the porphyritic granites. Mafic minerals are generally absent, but up to $3 \%$ biotite occurs, and epidote, chlorite and sericite are alteration products. Quartz shows significant recrystallization within small ductile shear zones characterized by 1 to $3 \mathrm{~mm}$ sized $\mathrm{K}$-feldspar clasts in a fine grained matrix of quartz. 

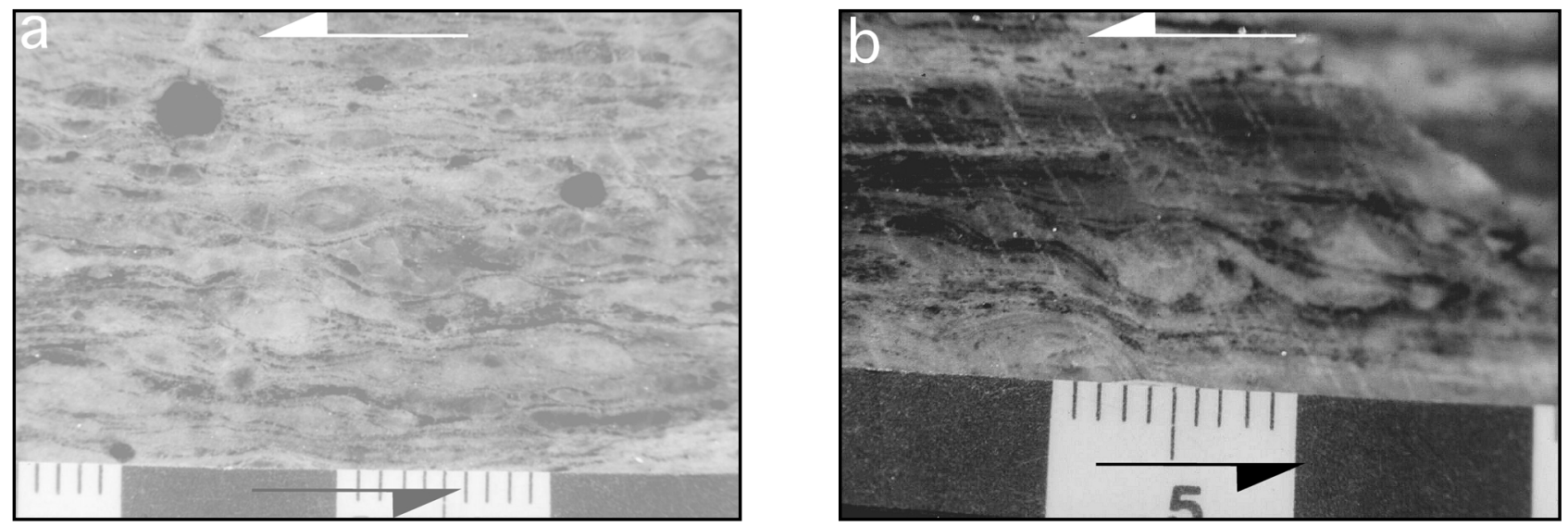

Figure 7. Cut and varnished sections of rock to show shear sense indicators in medium grade shear zones. (a) Sigma clasts (b) Delta clasts. Both show top to the left shear sense, which is reverse in the field frame of reference. Scale bar in $\mathrm{cm}$.

\section{Dolerites}

Dolerites occur as sills tens of $\mathrm{m}$ wide and hundreds of $\mathrm{m}$ long, parallel to the regional foliation and occupying 2 to $3 \%$ of the area, and as a dyke trending northnorthwest with a width of 10 to $15 \mathrm{~m}$ and a length of $10 \mathrm{~km}$ (Figure 2, the Nyamawanga dyke on the western boundary of the mapping area). Laths of plagioclase $\left(\mathrm{An}_{55}\right) 2$ to $3 \mathrm{~mm}$ in length are surrounded ophitically by clinopyroxene which is partly replaced by amphibole. Plagioclase edges in contact with pyroxene are partly replaced by chlorite and quartz. Olivine occurs in grains $0.3 \mathrm{~mm}$ in size. Quartz and biotite are accessories.

\section{Structural geology \\ Regional fabric and folds}

A regular regional foliation dipping about $55^{\circ}$ southsoutheast is found throughout the area, with a down-dip mineral lineation (Figures 2 and 5). The fabric intensity varies from weak to strong and is found in all major rock types except the dolerites. The fabric is defined by individual mineral grain shapes (feldspars, quartz, pyroxene, amphibole, and biotite) and by quartz grain aggregate shapes. This foliation is parallel to a weak gneissic banding in places.

A variety of $\mathrm{cm}$ - to $\mathrm{m}$-scale open to isoclinal folds were seen in outcrops of the felsic and granulite gneisses and enderbites. The folds are defined by layers with slight compositional variations or by quartz veins. Fold axes cannot easily be measured in most cases, but the few measurements taken show that the axes have no consistent orientation within the plane of the regional foliation. Fold axial surfaces are parallel to this plane.

\section{Fabrics in mafic granulites}

A striking exception to the general fabric is noted in the mafic granulite body in the southwest corner of the mapping area (Figure 2). The few measurements from clearly in-situ outcrops show that foliation strikes parallel to the margins of the mafic granulite and generally dips towards the centre of the body (Figures 2 and 5). Unfortunately, fabrics in the adjacent gneisses and the contact itself are not exposed. However, the occurrence of similar mafic granulites as deformed xenoliths in the gneisses (Figure 4b) suggests that this mafic granulite has been intruded by the gneisses and that the foliation is an earlier, possibly even magmatic, feature. The xenoliths have a compositional banding of orthopyroxene, hornblende and plagioclase that is discordant to the regional fabric in their hosts.

\section{Shear zones}

Two types of shear zone can be clearly distinguished in the field by their very different appearances, and also by deformation microstructures seen in thin section.

\section{Medium grade shear zones}

These shear zones define an anastomosing network of shears generally sub-parallel to the regional strike. They are characterised by a strong schistosity defined mainly by quartz, feldspar and biotite grains, and a strong lineation mostly defined by quartz. Petrological features of these shear zones are summarized in Table 2. Most of these shear zones contain down-dip mineral lineations (Figure 6), and asymmetric fabrics are seen in sections perpendicular to the foliation and parallel to the lineation. A particularly useful technique for rapid determination of shear sense from the coarser grained rock was to cut orientated samples perpendicular to the foliation and parallel to the lineation and apply varnish to the cut surface (Figure 7), which has several advantages over thin section or outcrop analysis:

(i) Shear sense indicators are examined in a plane which is accurately perpendicular to foliation and parallel to lineation compared to the generally nonideal surfaces of an outcrop;

(ii) A larger area can be examined than a thin section;

(iii) The method is more rapid than thin section preparation and has negligible costs;

(iv) The smooth varnished surface reveals details more clearly than a weathered outcrop surface.

Sigma and delta porphyroclasts and shear bands provide 
Table 2. Contrasts between medium and low grade shear zones

\begin{tabular}{|c|c|c|}
\hline & Medium grade shear zones & Low grade shear sones \\
\hline Fabric & $\begin{array}{l}\text { Strong schistosity of quartz, biotite and } \\
\text { feldspar grains. Strong quartz mineral } \\
\text { lineation }\end{array}$ & $\begin{array}{l}\text { Cataclastic texture: fractures separate rock into cm-sized } \\
\text { fragments (Figure } 8 \mathrm{~d} \text { ) }\end{array}$ \\
\hline $\begin{array}{l}\text { Shear Sense } \\
\text { Indicators }\end{array}$ & $\begin{array}{l}\sigma \text { and } \delta \text { porphyroclasts indicate reverse } \\
\text { shear }\end{array}$ & Rare S-C fabrics indicate reverse shear \\
\hline Quartz & $\begin{array}{l}1 \text { to } 2 \mathrm{~mm} \text { porphyroclasts (Figure } 8 \mathrm{~b} \text { ) } \\
\text { with undulatory extinction, subgrains, } \\
\text { ribbon grains } 1 \text { to } 2 \mathrm{~mm} \text { thick with } 0.2 \mathrm{~mm} \\
\text { grains, wrapping around garnet }\end{array}$ & Fractured (Figure 8f) \\
\hline Plagioclase & Deformation twins (Figure 8a) & $\begin{array}{l}0.6 \mathrm{~mm} \text { grains, deformation twins, altered to chlorite } \\
\text { and titanite }\end{array}$ \\
\hline Microcline & $\begin{array}{l}4 \mathrm{~mm} \text { porphyroclasts, extreme undulatory } \\
\text { extinction shown by spectacular deformation } \\
\text { of microperthite (Figure } 8 \mathrm{~b} \text { ) }\end{array}$ & $\begin{array}{l}1 \text { to } 2 \mathrm{~mm} \text { grains highly fractured and altered to sericite, } \\
\text { epidote and chlorite }\end{array}$ \\
\hline Mafic Minerals & $\begin{array}{l}\text { Biotite - strong preferred orientation } \\
\text { Garnet - ubiquitous fractured grains, } \\
\text { quartz pressure shadows }\end{array}$ & $\begin{array}{l}\text { Amphibole and pyroxene mostly or entirely replaced by } \\
\text { chlorite and titanite }\end{array}$ \\
\hline Other Features & $\begin{array}{l}\text { Orientated myrmekite intergrowths } \\
\text { (Figure 8c) at ends of plagioclase } \\
\text { porphyroclasts parallel to foliation }\end{array}$ & $\begin{array}{l}\text { Microshears of chlorite, titanite and epidote } 0.2-\text { to } 0.3 \mathrm{~mm} \\
\text { wide wrap around feldspars } \\
\text { ? Pseudotachylite }\end{array}$ \\
\hline $\begin{array}{l}\text { Deformation } \\
\text { Temperatures }\end{array}$ & $\begin{array}{l}400 \text { to } 500^{\circ} \mathrm{C} \text { from core-and-mantle } \\
\text { structures; orientated myrmekite gives } \\
\text { the upper part of this range }\end{array}$ & $\begin{array}{l}<400^{\circ} \mathrm{C} \text { (lack of plasticity in feldspars): perhaps lower due to } \\
\text { cataclasis in quartz }\end{array}$ \\
\hline
\end{tabular}

excellent shear sense indicators, particularly in the coarser grained rocks: the majority show reverse movement.

A medium grade shear zone over $50 \mathrm{~m}$ wide occurs in the northern part of the field area (Figure 2). This is part of a major structure known as the North Limpopo Thrust Zone (NLTZ, Blenkinsop et al., 1995), which separates the Zimbabwe craton from the NMZ. The foliation dips gently southeastwards and has a strong downdip mineral lineation (quartz and feldspar). Sigma and delta porphyroclasts clearly demonstrate reverse movement. At least one medium grade shear zone strikes northwestward and is continuous with a typical east-northeast striking shear zone (northeastern corner of Figure 2). Foliation in the ENE-striking portion curves around to assume a northwestern strike, but lineations on both the northwest and east-northeast striking portions of the shear zone are parallel (Figure 6). This indicates that both shear zones formed during the same event. The east-northeast striking section has pure reverse movement, while the northwest striking section has a dominant dextral, strike-slip movement. The characteristic microstructural feature of these shear zones is crystal plastic deformation of quartz and feldspar (Table 2): inferred temperatures for deformation are 400 to $500^{\circ} \mathrm{C}$ (Table 2).

\section{Low grade shear zones}

Five low grade shear zones occur within the study area (Figure 2). They are characterized by abundant chlorite and fracturing along zones $10 \mathrm{~cm}$ to $2 \mathrm{~m}$ wide (Figure 8 , $\mathrm{d}$ to $\mathrm{f}$, Table 2 ). They are readily distinguished in the field from the medium grade zones by their dominantly cataclastic texture and green colouration due to chlorite. The maximum strike length of these deformation zones is $350 \mathrm{~m}$. They are separated by 2.5 to $4 \mathrm{~km}$ along strike and $5 \mathrm{~km}$ across strike. Like the medium grade shear zones, the low grade shear zones strike eastnortheastward and dip gently to moderately southeastward, with down dip chlorite and quartz mineral lineations (Figure 6).

An interesting aspect of these shear zones is the presence of planar zones up to $2 \mathrm{~cm}$ wide and a few $\mathrm{m}$ long parallel to fractures and containing large proportions of chlorite. Although the zones are generally planar, distinctive V-shaped triangular offshoots extend up to $10 \mathrm{~cm}$ from the planar zones into the wall-rock at angles of 45 to $60^{\circ}$ in the plane perpendicular to the foliation and parallel to the lineation (Figure 9, a and b). The zones contain angular to sub-angular quartz clasts and equant opaque grains 2 to $200 \mu \mathrm{m}$ in size in a matrix of brown, very fine grained, high relief material, partly comprised of chlorite and very fine grained phyllosilicates (Figure 9b). A very weak foliation is defined by the phyllosilicates, at a high angle to the margins. The opaque grains are generally scattered throughout these zones, but also may be concentrated in bands along and adjacent to the margins. The margins of the zones are generally sharp and planar, but in places where chlorite lies in the host rock along the edge of the zones, the margins are embayed. In situ fragmentation of quartz and feldspars occurs along the margins in places. 

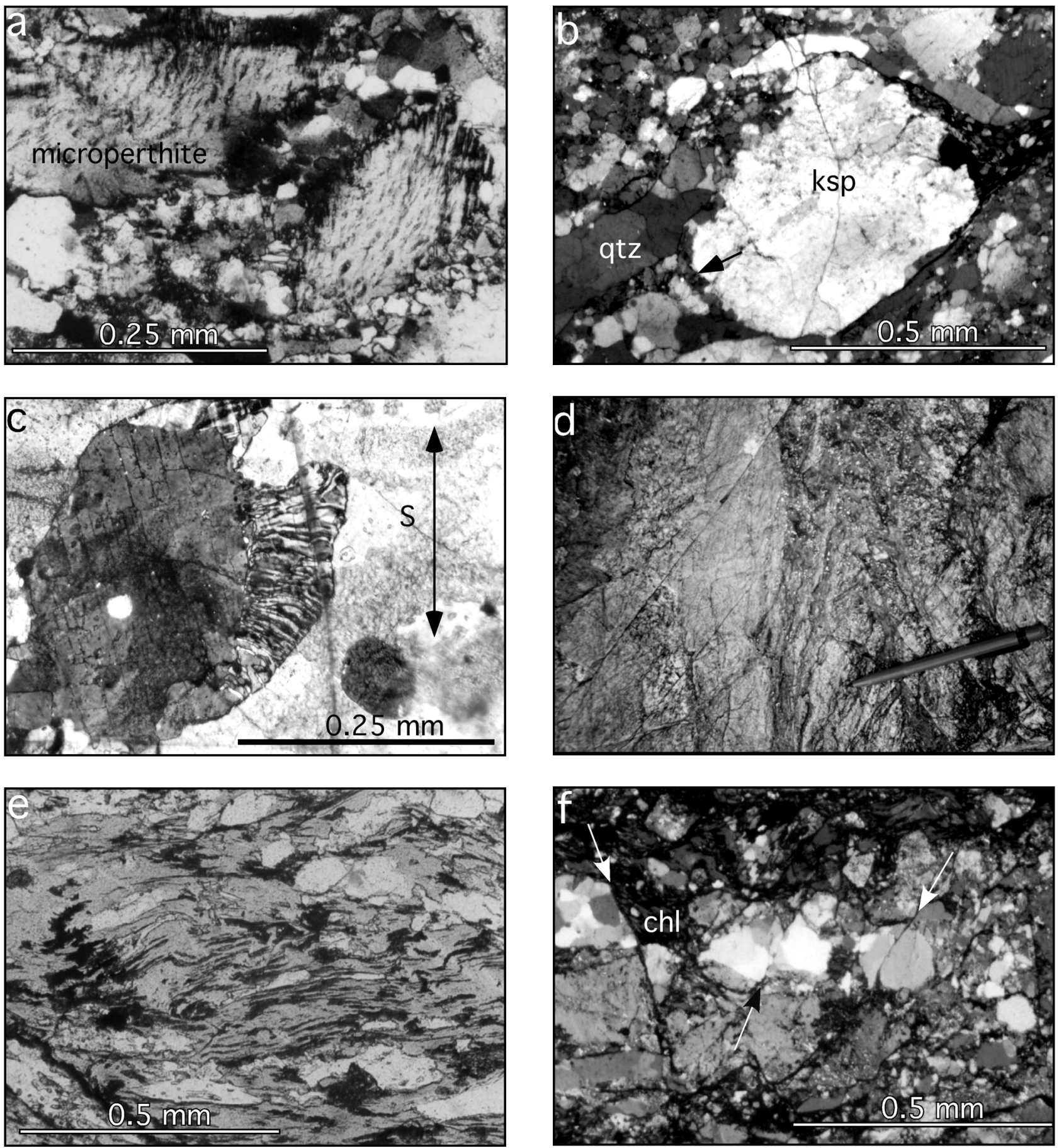

Figure 8. Contrast between microstructures of the medium and low grade shear zones.

(a) Medium grade shear zones, showing crystal plastic deformation of feldspars (microperthite). Crossed polars. (b) Medium grade shear zone, showing quartz ribbons (qtz) wrapping around K-feldspar (ksp), and dynamic recrystallization of K-feldspar (e.g. arrow). Crossed polars. (c) Medium grade shear zone showing myrmekite growth on face of feldspar porphyroclast parallel to foliation (S). Crossed polars. (d) Low-grade shear zone to show typical field appearance. Characteristic cataclastic texture above pen (10cm). (e) Low grade shear zone mainly composed of chlorite with small asymmetrical folds. Plain polarized light. (f) Low grade shear zone, mostly chlorite (chl) and quartz, which is fractured (arrows). Crossed polars.

Many of the above characteristics are compatible with a pseudotachylite origin for the material in the zones, such as their occurrence as planar fractures, which can be considered as generation surfaces. The triangular offshoots have a comparable geometry to injection veins as described in pseudotachylites (e.g.
Passchier and Trouw 1996). The mineral composition of the matrix is compatible with a devitrified and recrystallised glass. The fragments in the matrix, evidence for fragmentation along the zone margins (e.g. Grocott 1981, Magloughlin 1989), and embayments in hydrous minerals along the margins of the zones are 

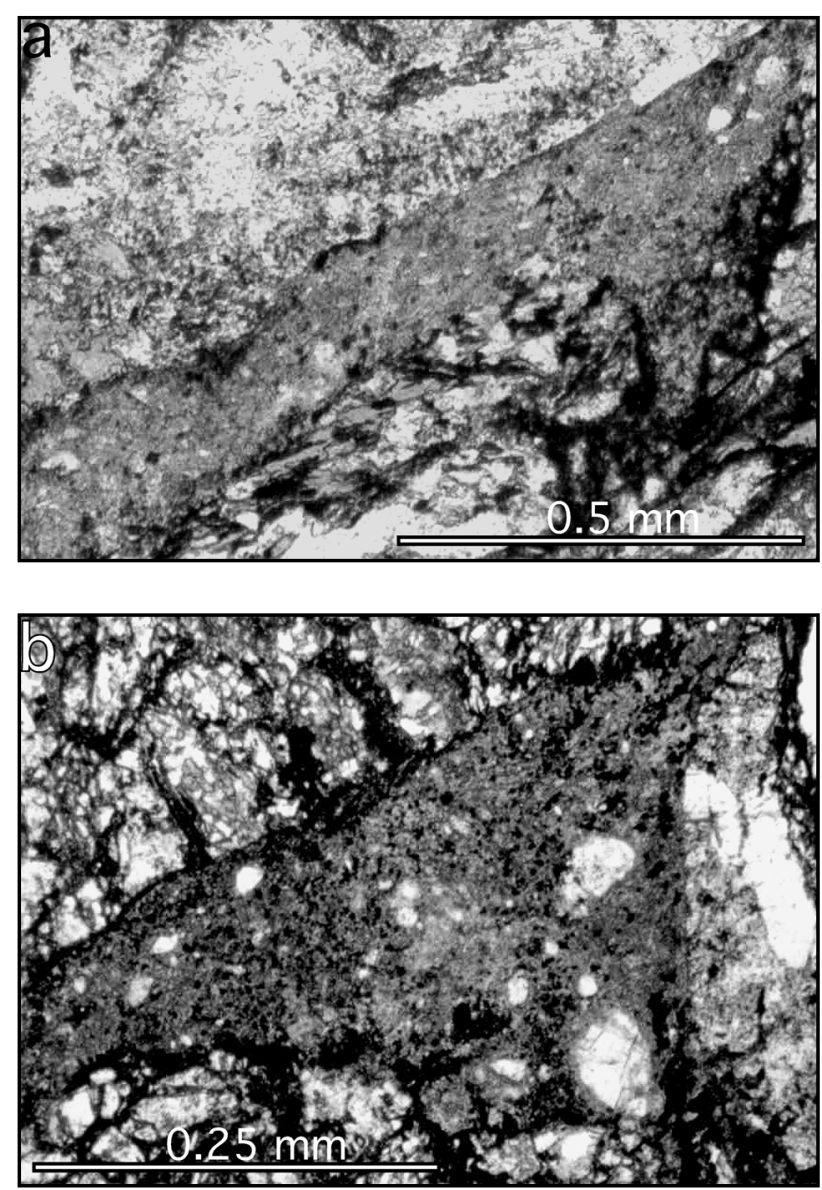

Figure 9. Photomicrographs of possible devitrified pseudotachylite. (a) Zone of high relief brown material. Distinctive triangular V-shaped offshoot of vein is visible on right hand side. (b) Close up of a triangular V-shaped offshoot interpreted as an injection vein. Sub-angular to sub-rounded clasts of quartz in matrix.

characteristic of preferential melting of hydrous phases in pseudotachylites (e.g. Maddock 1992, Camacho et al. 1995). It is not possible to prove conclusively that these zones are pseudotachylites generated by frictional melting as well as cataclasis (cf. Spray 1995) without further detailed analysis, but the evidence is strongly suggestive. These zones formed during/after the low grade shear zones which they cut. Their exclusive association with the low grade shear zones, and the presence of chlorite and a foliation in the recrystallised matrix of the zones suggests that they may have been formed the later stages of this deformation. Temperature conditions during formation of the low grade shear zones are constrained to less than $400^{\circ} \mathrm{C}$ (Table 2).

\section{Geochronology \\ Analytical technique}

We employed the single zircon evaporation technique to date grains of samples of possibly intrusive rocks which could constrain the tectonic history of the area. Our laboratory procedures follow Kober $(1986 ; 1987)$ with slight modifications (Kröner et al., 1991, Kröner and
Hegner, 1998). Isotopic measurements were carried out on a Finnigan-MAT 261 mass spectrometer at the MaxPlanck-Institut für Chemie in Mainz. No correction was made for mass fractionation of $\mathrm{Pb}$ which is $0.3 \% \mathrm{o}$ per mil per atomic mass unit (W. Todt, pers. comm. 1997). This correction is insignificant at the age range considered in this study. During the course of this study we have repeatedly analyzed fragments of large, euhedral, colourless to slightly pink, homogeneous zircon grains from the Palaborwa Complex, South Africa. Two zircon fragments from this sample were analyzed on SHRIMP II in Perth and yielded a concordant ${ }^{207} \mathrm{~Pb} /{ }^{206} \mathrm{~Pb}$ age of $2050 \pm 12 \mathrm{Ma}$, whereas ID-TIMS U-Pb analyses of six separate grain fragments from the same sample yielded a ${ }^{207} \mathrm{~Pb} /{ }^{206} \mathrm{~Pb}$ age of $2052.2 \pm 0.8 \mathrm{Ma}$ $(2 \sigma)$ (W. Todt, unpubl. data). The mean ${ }^{207} \mathrm{~Pb} /{ }^{206} \mathrm{~Pb}$ ratio for 18 grains, evaporated individually over a period of 12 months, is $0.126634 \pm 0.000027$ ( $2 \sigma$ error of the population), corresponding to an age of $2051.8 \pm 0.4 \mathrm{Ma}$, identical to the U-Pb age. The above error is considered the best estimate for the reproducibility of our evaporation data and corresponds approximately to the $2 \sigma$ (mean) error reported for individual analyses in this study (Table 1). In the case of combined data sets the $2-\sigma_{\mathrm{m}}$ error may become very low, and whenever this error was less than the reproducibility of the internal standard, we have used the latter value (that is, an assumed $2 \sigma$ error of 0.000027 ).

In our experiments evaporation temperatures were gradually increased in $20-30^{\circ} \mathrm{C}$ steps during repeated evaporation-deposition cycles until no further changes in the ${ }^{207} \mathrm{~Pb} /{ }^{206} \mathrm{~Pb}$ ratios were observed. Only data from the high-temperature runs or those with no changes in the Pb-isotope ratios were con-sidered for geochronologic evaluation. The calculated ${ }^{207} \mathrm{~Pb} /{ }^{206} \mathrm{~Pb}$ ratios and their 2-sigma (mean) errors are based on the means of all measurements evaluated and are presented in Table 1. Ages and errors for several zircons from the same sample are presented as weighted means of the entire population. The ${ }^{207} \mathrm{~Pb} /{ }^{206} \mathrm{~Pb}$ spectra are shown in histograms to permit visual assessment of the data distribution from which the ages are derived.

Since the evaporation technique only provides $\mathrm{Pb}$ isotopic ratios, there is no a priori way to determine whether a measured ${ }^{207} \mathrm{~Pb} /{ }^{206} \mathrm{~Pb}$ ratio reflects a concordant age. Thus, principally, all ${ }^{207} \mathrm{~Pb} /{ }^{206} \mathrm{~Pb}$ ages determined by this method are necessarily minimum ages. However, it has been shown in many studies that there is a very strong likelihood of these data to represent true zircon crystallization ages (1) when the ${ }^{207} \mathrm{~Pb} /{ }^{206} \mathrm{~Pb}$ ratio does not change with increasing temperature of evaporation and/or (2) when repeated analysis of grains from the same sample at high evaporation temperatures yield the same isotopic ratios within error. The rationale behind this is that it is highly unlikely that each grain in a zircon population has lost exactly the same amount of $\mathrm{Pb}$, and that grains with $\mathrm{Pb}$ loss appreciably prior to the Present would therefore yield highly variable ${ }^{207} \mathrm{~Pb} /{ }^{206} \mathrm{~Pb}$ ratios and ages. 


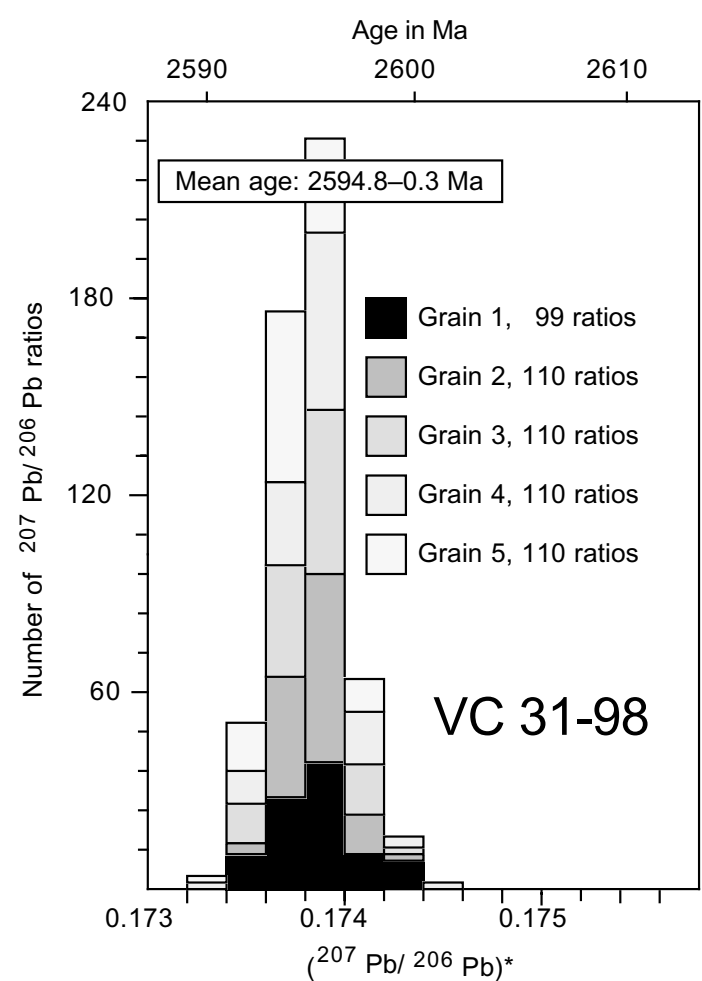

(a)

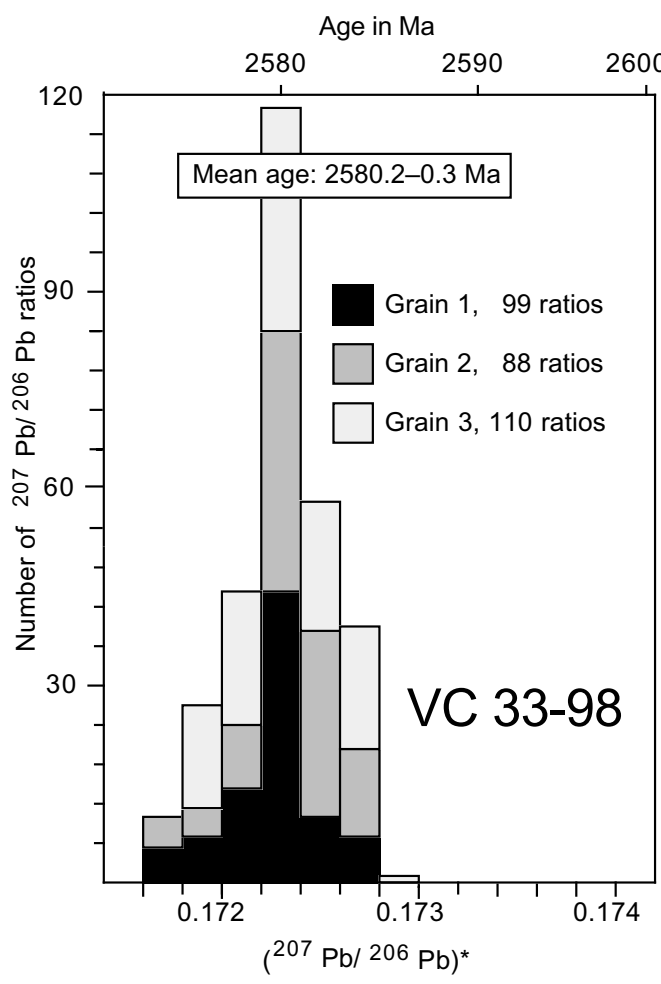

(c)

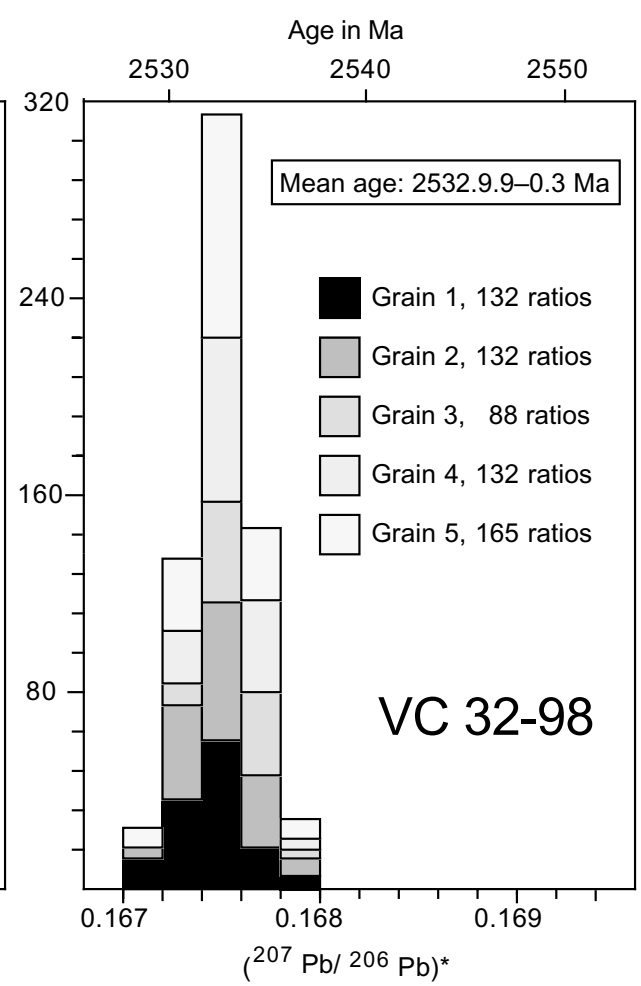

(b)

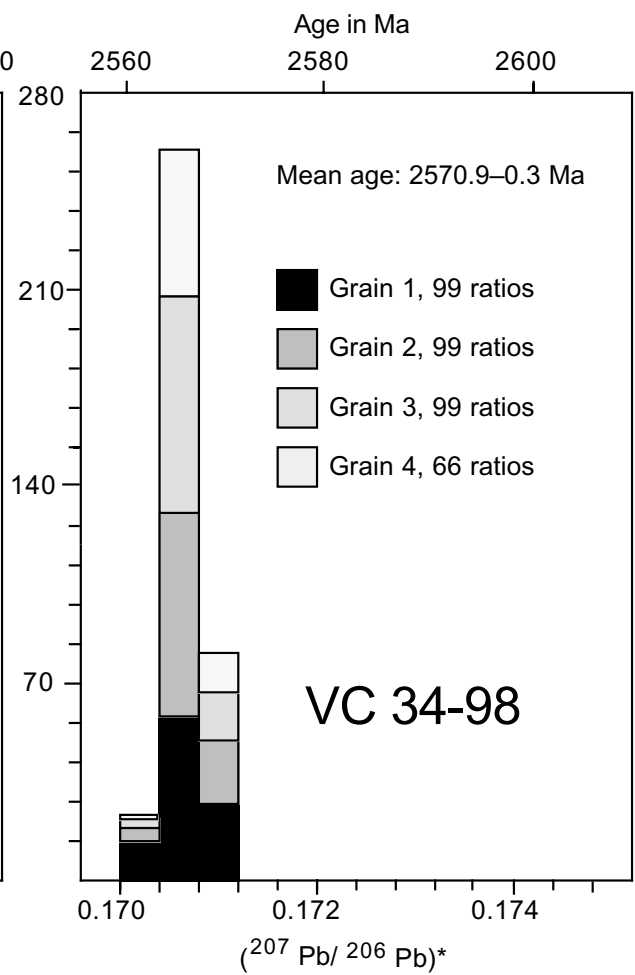

(d)

Figure 10. Histograms showing distribution of radiogenic lead isotope ratios derived from evaporation of single zircons from samples in the Renco Mine area, NMZ, Limpopo belt, Zimbabwe. (a) Spectrum for 5 grains from Razi granite sample VC 31-98, integrated from 539 ratios. (b) Spectrum for 5 grains from pegmatitic granite sample VC 32-98, integrated from 649 ratios. (c) Spectrum for 3 grains from augen-gneiss sample VC 33-98, integrated from 279 ratios. (d) Spectrum for 4 grains from enderbitic gneiss sample VC 34-98, integrated from 363 ratios. 


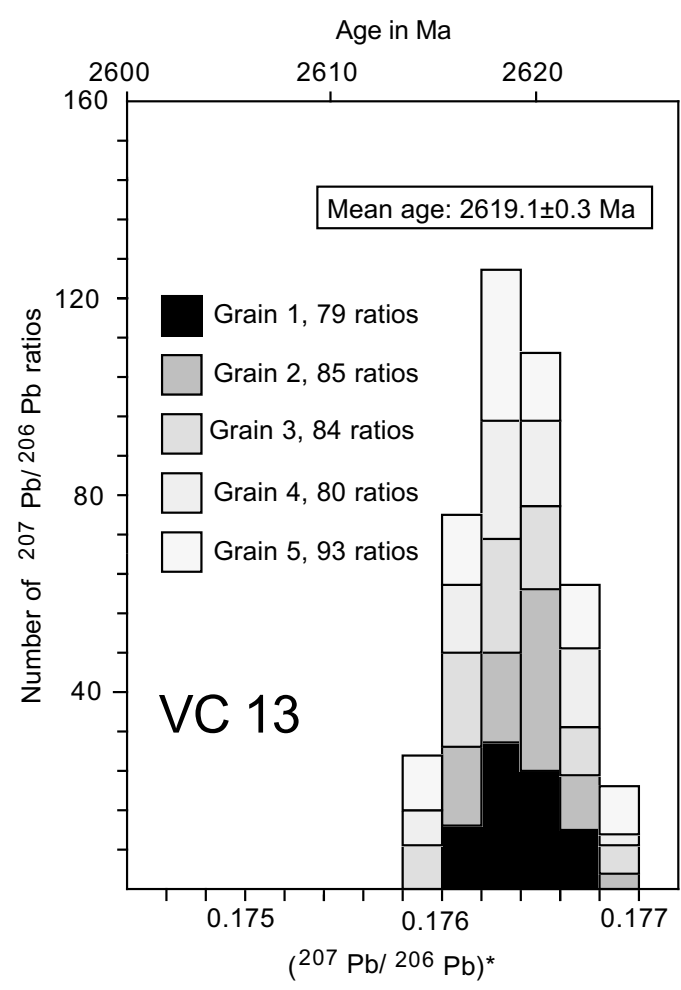

(a)

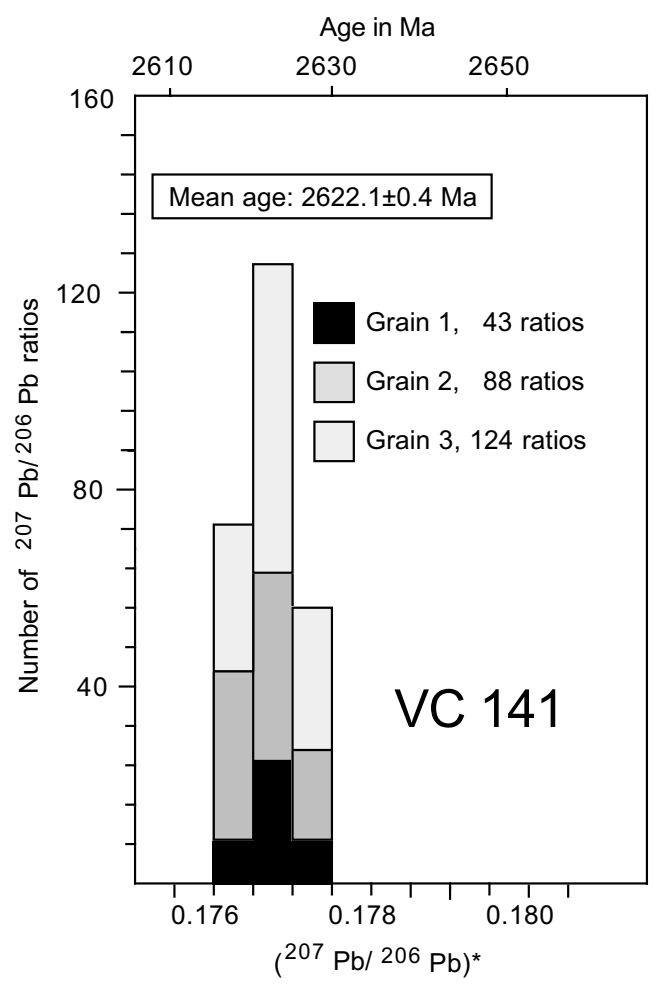

(c)

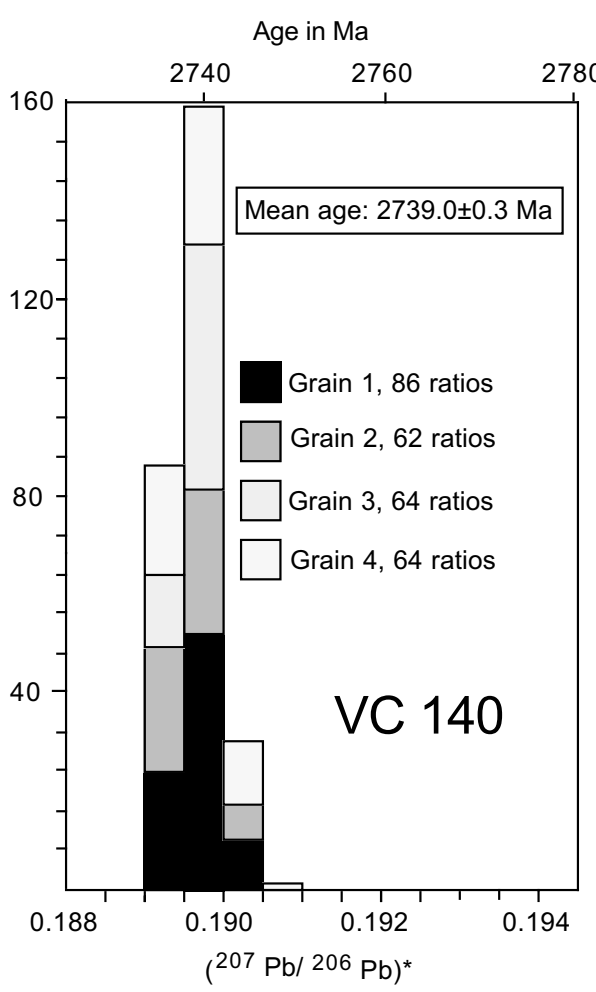

(b)

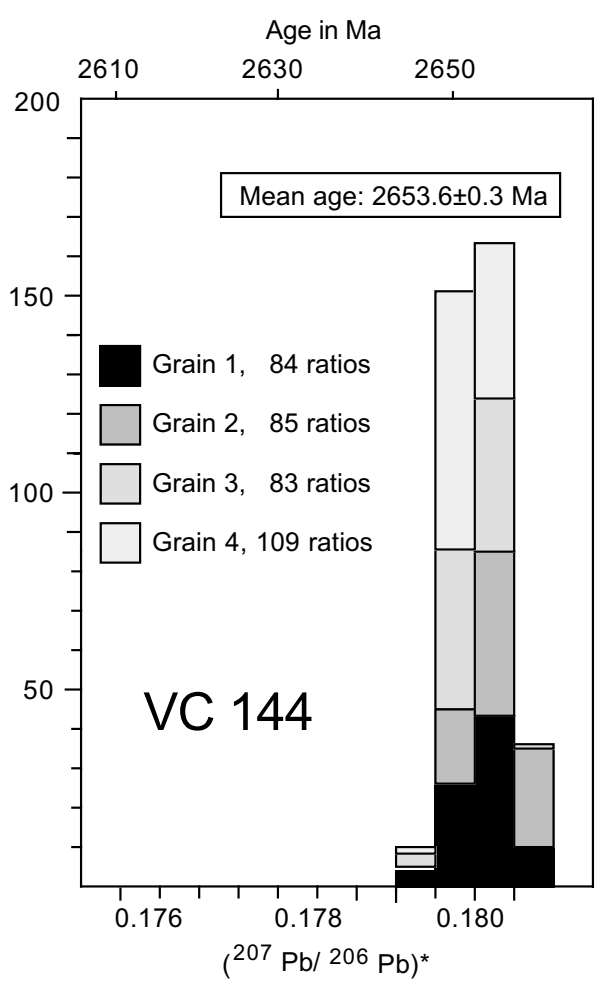

(d)

Figure 11. Histograms showing distribution of radiogenic lead isotope ratios derived from evaporation of single zircons from samples in the Renco Mine area, NMZ, Limpopo belt, Zimbabwe. (a) Spectrum for 5 grains from felsic gneiss sample VC 13, integrated from 328 ratios. (b) Spectrum for 4 grains from enderbitic gneiss sample VC 140, integrated from 276 ratios. (c) Spectrum for 3 grains from enderbitic gneiss sample VC 141, integrated from 255 ratios. (d) Spectrum for 4 grains from felsic gneiss sample VC 144, integrated from 361 ratios. 
Table 3. Summary of results from dating samples in the Renco mine area of the Northern Marginal Zone.

\begin{tabular}{|c|c|c|c|c|}
\hline $\begin{array}{l}\text { Sample, } \\
\text { Rock Type }\end{array}$ & UTM & Notes on sample & Age, Ma & Interpretation \\
\hline $\begin{array}{l}\text { VC 31-98 } \\
\text { Razi granite }\end{array}$ & $\begin{array}{r}308600 \\
7730900\end{array}$ & $\begin{array}{l}\text { Megacrystic, coarse-grained, pink to } \\
\text { light grey rock. K-feldspars } \\
2 \mathrm{~cm} \times 0.5-0.75 \mathrm{~cm} \text { weakly elongated, } \\
\text { parallel to the regional fabric, mineral } \\
\text { lineation plunging } \mathrm{S} \text { in zones. }\end{array}$ & $2594.8 \pm 0.3$ & $\begin{array}{l}\text { Zircons typical of igneous growth in a } \\
\text { granitoid magma. Time of igneous } \\
\text { emplacement of the Razi granite. }\end{array}$ \\
\hline $\begin{array}{l}\text { VC } 32-98 \\
\text { Granite } \\
\text { pegmatite }\end{array}$ & $\begin{array}{r}309500 \\
7730400\end{array}$ & $\begin{array}{l}\text { Epidotised and weakly deformed from } \\
\text { zone of altered pegmatites parallel to } \\
\text { regional fabric. }\end{array}$ & $2594.8 \pm 0.3$ & $\begin{array}{l}\text { Zircons similar to previous sample; Time of } \\
\text { igneous emplacement of the pegmatitic } \\
\text { granite. }\end{array}$ \\
\hline $\begin{array}{l}\text { VC 33-98 } \\
\text { Augen-gneiss }\end{array}$ & $\begin{array}{r}309600 \\
7729600\end{array}$ & $\begin{array}{l}\text { Gneiss derived from porphyritic granite } \\
\text { Strong foliation dipping gently to the } \\
\text { southeast with a lineation plunging } \\
\text { southeast defined by quartz. }\end{array}$ & $2580.2 \pm 0.3$ & $\begin{array}{l}\text { Zircons have metamorphic "corrosion" as } \\
\text { typical in high-grade metamorphic rocks } \\
\text { (Kröner et al., 1994). Time of igneous } \\
\text { emplacement of the gneiss precursor. }\end{array}$ \\
\hline $\begin{array}{l}\text { VC 34-98 } \\
\text { Enderbite }\end{array}$ & $\begin{array}{r}95800 \\
7721450\end{array}$ & Leucocratic: Similar to Renco enderbite. & $2570.9 \pm 0.3$ & $\begin{array}{l}\text { Zircons as in VC 98-33. Time of igneous } \\
\text { emplacement of the enderbite precursor. }\end{array}$ \\
\hline $\begin{array}{l}\text { VC } 13 \\
\text { Granitoid gneiss }\end{array}$ & $\begin{array}{r}306800 \\
7712600 \\
\end{array}$ & $\begin{array}{l}\text { Strongly foliated and downgraded, within } \\
\text { a chlorite shear zone. }\end{array}$ & $2619.1 \pm 2$ & Time of emplacement of the gneiss protolith. \\
\hline $\begin{array}{l}\text { VC } 140 \\
\text { Enderbitic } \\
\text { gneiss }\end{array}$ & $\begin{array}{r}281600 \\
7706650\end{array}$ & $\begin{array}{l}\text { Massive to weakly foliated rock with } \\
\text { minor disseminated chalcopyrite: } \\
\text { Mukorsi Dam. }\end{array}$ & $2739.0 \pm 0.3$ & Time of emplacement of the enderbite. \\
\hline $\begin{array}{l}\text { VC } 141 \\
\text { Enderbite }\end{array}$ & $\begin{array}{r}281600 \\
7706650\end{array}$ & $\begin{array}{l}\text { Massive, coarse-grained, a few metres } \\
\text { from sample VC } 140 . \text { In segregations } \\
\text { along axial surfaces of folds in the } \\
\text { enderbitic gneiss: Mukorsi Dam. }\end{array}$ & $2622.1 \pm 0.4$ & Time of enderbite segregation. \\
\hline $\begin{array}{l}\text { VC } 144 \\
\text { Felsic gneiss }\end{array}$ & $\begin{array}{r}306850 \\
7723200\end{array}$ & Medium-grained melanocratic. & $2653.6 \pm 0.3$ & Time of gneiss protolith emplacement. \\
\hline
\end{tabular}

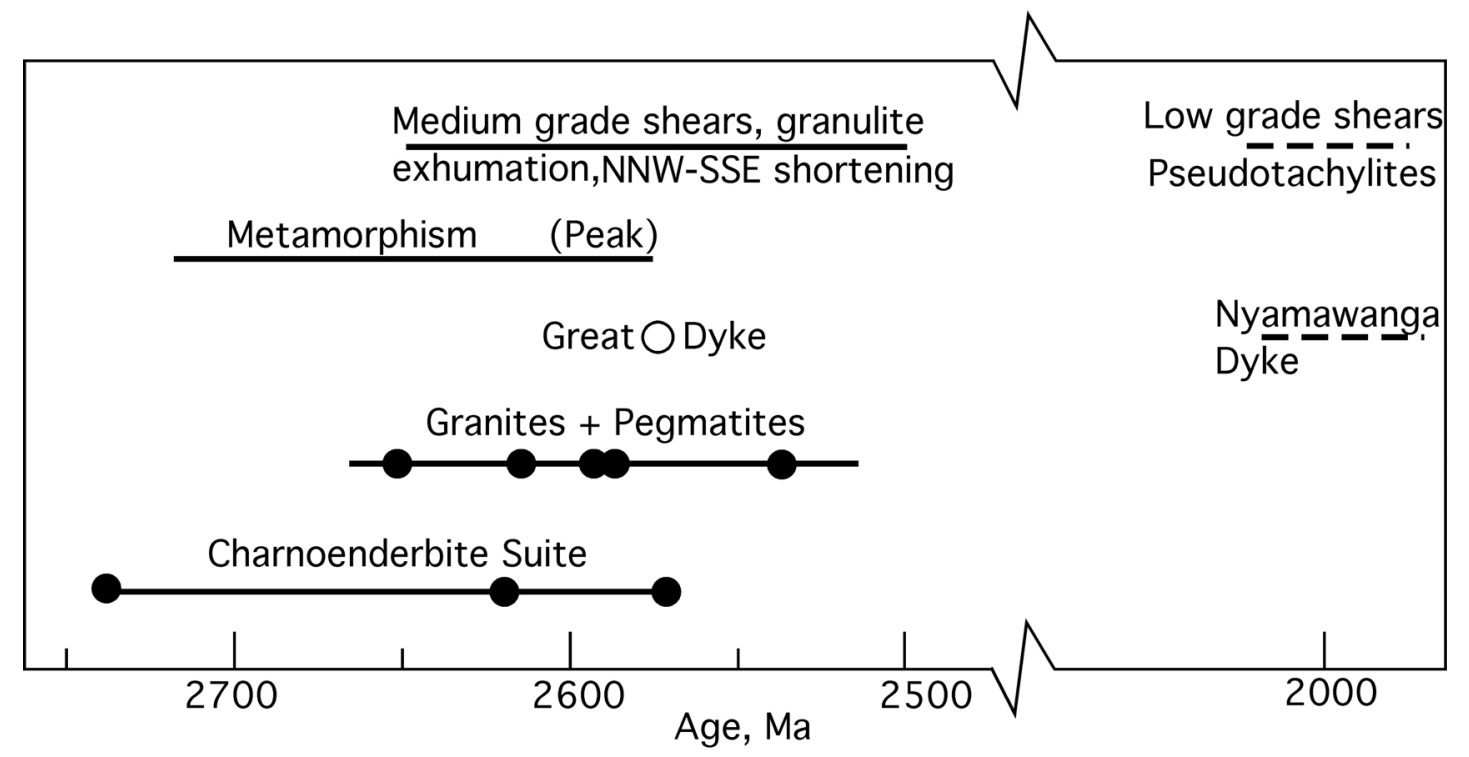

Figure 12. Schematic intrusive, metamorphic and deformation history of the late Archaean of the Northern Marginal Zone, Limpopo Belt, based on Kamber and Biino (1995), Berger et al. (1995), Frei et al. (1999), and this study. Note discontinuity in age scale. Solid circles indicate intrusive ages obtained in this study. Results from grantic rocks obtained here have been grouped together with previously published ages from the Razi granites to indicate the period of granite (sensu lato) intrusion. Dashed lines indicate lack of detailed geochronological constraints. Deformation and intrusive events may be diachronous across the NMZ. 
Table. 4. Isotopic data from single grain zircon evaporation

\begin{tabular}{|c|c|c|c|c|c|c|}
\hline $\begin{array}{l}\text { Sample } \\
\text { Number }\end{array}$ & $\begin{array}{l}\text { Zircon colour } \\
\text { and Morphology }\end{array}$ & $\begin{array}{c}\text { Grain } \\
\#\end{array}$ & $\begin{array}{l}\text { Mass } \\
\text { cans }^{1}\end{array}$ & $\begin{array}{l}\text { Evaporation } \\
\text { temp. in }{ }^{\circ} \mathrm{C}\end{array}$ & $\begin{array}{c}\text { Mean }{ }^{207} \mathrm{~Pb} /{ }^{206} \mathrm{~Pb} \\
\text { ratio }^{2} \text { and } 2-\sigma \mathrm{m} \text { error }\end{array}$ & $\begin{array}{r}{ }^{207} \mathrm{~Pb} /{ }^{206} \mathrm{~Pb} \text { age } \\
\text { and } 2-\sigma \mathrm{m} \text { error }\end{array}$ \\
\hline VC31-98 & dark red, & 1 & 99 & 1605 & $0.173846 \pm 42$ & $2595.0 \pm 0.4$ \\
\hline \multirow[t]{4}{*}{ Razi granite } & long-prismatic, & 2 & 110 & 1603 & $0.173840 \pm 26$ & $2595.0 \pm 0.3$ \\
\hline & idiomorphic & 3 & 110 & 1602 & $0.173821 \pm 33$ & $2594.8 \pm 0.3$ \\
\hline & & 4 & 110 & 1601 & $0.173861 \pm 37$ & $2595.2 \pm 0.4$ \\
\hline & & 5 & 110 & 1605 & $0.173767 \pm 33$ & $2594.3 \pm 0.3$ \\
\hline mean of 5 grains & & $1-5$ & 539 & & $0.173827 \pm 15$ & $* 2594.8 \pm 0.3$ \\
\hline VC32-98 & dark red, & 1 & 132 & 1602 & $0.167442 \pm 32$ & $2532.2 \pm 0.3$ \\
\hline \multirow[t]{4}{*}{ Granite pegmatite } & long-prismatic, & 2 & 132 & 1604 & $0.167499 \pm 29$ & $2532.8 \pm 0.3$ \\
\hline & idiomorphic & 3 & 88 & 1606 & $0.167590 \pm 29$ & $2533.7 \pm 0.3$ \\
\hline & & 4 & 132 & 1600 & $0.167537 \pm 27$ & $2533.2 \pm 0.3$ \\
\hline & & 5 & 165 & 1602 & $0.167499 \pm 26$ & $2532.8 \pm 0.3$ \\
\hline mean of 5 grains & & $1-5$ & 649 & & $0.167508 \pm 13$ & $* 2532.9 \pm 0.3$ \\
\hline vC33-98 & dark redbrown & 1 & 99 & 1599 & $0.172284 \pm 50$ & $2580.1 \pm 0.5$ \\
\hline \multirow[t]{2}{*}{ Augen-gneiss } & long-prismatic, & 2 & 88 & 1601 & $0.172306 \pm 47$ & $2580.2 \pm 0.5$ \\
\hline & ends well rounded & 3 & 110 & 1592 & $0.172315 \pm 53$ & $2580.3 \pm 0.5$ \\
\hline mean of 3 grains & & $1-3$ & 279 & & $0.172305 \pm \quad 29$ & ${ }^{*} 2580.2 \pm 0.3$ \\
\hline VC34-98 & dark redbrown & 1 & 99 & 1601 & $0.171351 \pm 58$ & $2570.9 \pm 0.6$ \\
\hline \multirow[t]{3}{*}{ Enderbite } & long-prismatic, ends & 2 & 99 & 1599 & $0.171346 \pm 50$ & $2570.9 \pm 0.6$ \\
\hline & ends rounded & 3 & 99 & 1606 & $0.171357 \pm 35$ & $2570.9 \pm 0.3$ \\
\hline & & 4 & 99 & 1599 & $0.171344 \pm 44$ & $2570.8 \pm 0.4$ \\
\hline mean of 4 grains & & $1-4$ & 363 & & $0.171350 \pm 24$ & $* 2570.9 \pm 0.3$ \\
\hline VC 13 & dark red, & 1 & 79 & 1602 & $0.176387 \pm 40$ & $2619.2 \pm 0.4$ \\
\hline Granitoid & long-prismatic, & 2 & 85 & 1600 & $0.176402 \pm 46$ & $2619.3 \pm 0.4$ \\
\hline \multirow[t]{3}{*}{ gneiss } & idiomorphic & 3 & 84 & 1600 & $0.176367 \pm 60$ & $2619.0 \pm 0.6$ \\
\hline & to slightly & 4 & 80 & 1598 & $0.176373 \pm 54$ & $2619.1 \pm 0.5$ \\
\hline & rounded at ends & 5 & 93 & 1600 & $0.176378 \pm 65$ & $2619.1 \pm 0.6$ \\
\hline mean of 5 grains & & $1-5$ & 328 & & $0.176381 \pm 24$ & $* 2619.1 \pm 0.3$ \\
\hline VC 140 & medium to dark & 1 & 86 & 1597 & $0.189665 \pm 53$ & $2739.3 \pm 0.5$ \\
\hline Enderbitic & brown, stubby to & 2 & 62 & 1598 & $0.189594 \pm 73$ & $2738.6 \pm 0.6$ \\
\hline \multirow[t]{2}{*}{ Gneiss } & long-prismatic & 3 & 64 & 1599 & $0.189606 \pm 39$ & $2738.7 \pm 0.3$ \\
\hline & ends well rounded & 4 & 64 & 1598 & $0.189638 \pm 91$ & $2739.0 \pm 0.8$ \\
\hline mean of 4 grains & & $1-4$ & 276 & & $0.189629 \pm 33$ & $2738.9 \pm 0.3$ \\
\hline VC 141 & grey,- & 1 & 43 & 1589 & $0.176741 \pm 100$ & $2622.5 \pm 0.9$ \\
\hline \multirow[t]{2}{*}{ Enderbite } & long-prismatic, & 2 & 88 & 1587 & $0.176634 \pm 82$ & $2621.5 \pm 0.8$ \\
\hline & ends little rounded & 3 & 124 & 1598 & $0.176729 \pm 58$ & $2622.4 \pm 0.5$ \\
\hline mean of 3 grains & & $1-3$ & 255 & & $0.176698 \pm 43$ & $2622.1 \pm 0.4$ \\
\hline VC 144 & light brown to red, & 1 & 84 & 1598 & $0.180134 \pm 70$ & $2654.1 \pm 0.6$ \\
\hline \multirow[t]{3}{*}{ Gneiss } & long-prismatic & 2 & 85 & 1598 & $0.180286 \pm 77$ & $2655.5 \pm 0.7$ \\
\hline & ends little rounded & 3 & 83 & 1596 & $0.179985 \pm 61$ & $2652.7 \pm 0.6$ \\
\hline & & 4 & 109 & 1599 & $0.179934 \pm 47$ & $2652.3 \pm 0.4$ \\
\hline mean of 4 grains & & $1-4$ & 361 & & $0.180075 \pm 35$ & $2653.6 \pm 0.3$ \\
\hline
\end{tabular}

${ }^{1}$ Number of ${ }^{207} \mathrm{~Pb} /{ }^{206} \mathrm{~Pb}$ ratios evaluated for age assessment. ${ }^{2}$ Observed mean ratio corrected for non radiogenic Pb where necessary. Errors based on uncertainties in counting statistics. *Error based on reproducibility of internal standard.

Comparative studies by single grain evap-oration, conventional $\mathrm{U}-\mathrm{Pb}$ dating and ion-microprobe analysis have shown this to be correct (e.g. Kröner et al., 1991; Cocherie et al., 1992; Jaeckel et al., 1997).

\section{Samples and results}

Samples and Results are summarized in Table 3, and details of zircons and isotopic data are given in Table 4 . The descriptions in Table 3 emphasise the fabrics of the rocks, because the major aim of the dating program was to constrain the deformational/metamorphic history of these rocks.

\section{Discussion}

Tectonic history of the study area

Figure 12 summarises the tectonic history of the study area. The oldest rocks in the study area known at present are the mafic granulites and associated iron formations. This study constrains their age to a minimum of $\sim 2654$ Ma given by the felsic gneisses that contain 
these rocks, in agreement with previous work (Berger et al., 1995; Berger and Rollinson, 1997). It is possible that these rocks are also older than the oldest enderbite ( $\sim 2739 \mathrm{Ma})$ which appears to postdate the felsic gneisses because of its massive appearance. The geochemistry of some mafic granulites in the NMZ is similar to mafic greenstones of the Zimbabwe Craton (Rollinson and Lowrie, 1992), suggesting that the mafic granulites and the iron formation in the study area are equivalents of parts of greenstone belts in the Craton.

Most of the rocks in the study area are felsic intrusive rocks of the charnoenderbite suite or their retrogressed equivalents. The emplacement age of the enderbite at Mukorsi Dam reported here $(\sim 2739 \mathrm{Ma})$ extends the upper limit of the age range ( 2710 to $\sim 2603 \mathrm{Ma}$ ) given previously by Berger et al. (1995) for this period of major igneous intrusions, which probably involved remelting of crustal precursors that originally formed $\sim 3000 \mathrm{Ma}$ ago (Figure 12).

The enderbite date of $2571 \pm 0.3$ Ma given by sample VC34-98 is the same age as the Renco enderbite (2571 \pm 5 Ma; Blenkinsop and Frei, 1996). These dates demonstrate that the last phase of the charnoenderbite suite is younger than the age of some of the local Razi suite granites ( $2595 \pm 0.3 \mathrm{Ma}$ ), given by sample VC31-98. At least in the Renco area, a temporal distinction between the charnoenderbites and the Razi suite cannot be maintained, contra Kramers et al. (2001). The $168 \mathrm{Ma}$ age difference between the intrusion of the Mukorsi Dam and petrographically similar Renco enderbites demonstrates that intrusive activity had a long-lived nature, and also cautions strongly against the use of petrographic similarities to make stratigraphic correlations in the Limpopo belt. Kramers et al. (2001) have explained this long period of intrusive activity as a consequence of the very radiogenic composition of the NMZ rocks combined with a slightly enhanced mantle heat flux.

Evidence for a pre-2.7 Ga metamorphic history for the area has been given by Kamber and Biino (1995) on the basis of fabrics in mafic xenoliths. These authors established that the major metamorphic event in the NMZ (Stage 3) involved an anticlockwise PT loop from $\sim 2.72$ to $\sim 2.58 \mathrm{Ga}$ on the basis of typical reactions of such paths, such as orthopyroxene + plagioclase -> garnet + quartz in metasediments, with a peak at $\sim 2.59$ $\mathrm{Ga}$ and possibly multiple metamorphic events. The alternative clockwise PT loops of Tsunogae et al. (1992) for the Archaean are not appropriate, because they contain points that were derived from samples separated by tens of kilometres, and because they include samples representing both the Archaean and Proterozoic metamorphic events (Kamber and Biino 1995). Peak metamorphism in the NMZ is considered to have been coeval with the intrusion of the Razi granites. The prograde reaction (1) recorded by plagioclase-orthopyroxene symplectites in mafic granulites and felsic gneisses can be associated with this event.
However, the retrograde reactions (2) and replacement of orthopyroxene by hornblende are difficult to place within an absolute time frame. Although regarded as a distinct, Palaeoproterozoic event by Kamber and Biino (1995, Stage 4), evidence summarised below suggests that structural manifestations of the latter event are limited to the distinctive chlorite-rich low grade shear zones, and thus the retrograde reactions could be the latter part of the late Archaean metamorphism, as previously suggested (e.g. Mkweli, 1998).

The major deformation in the study area gave rise to a pervasive regional east-northeast fabric and was also localized along medium grade shear zones sub-parallel to this fabric. The most important of these is the NLTZ, along which the NMZ was thrust onto the Zimbabwe Craton with pure dip-slip movement from the southeast. A medium grade shear zone that strikes northwest has a lineation in a similar orientation to the east-northeast medium grade shear zones, and acted as a lateral ramp. This study suggests that some deformation lasted until at least $2533 \mathrm{Ma}$ (intrusive age of the weakly deformed pegmatite sample VC 32-98), which is compatible with the effects of the deformation on a Razi granite within the study area with an age of $2517 \pm 55 \mathrm{Ma}$ (Frei et al., 1999).

The new ages for the Razi granite and related rocks reported here (samples VC 31-98 and VC 32-98) follow the general trend of younging to the east as reported by Frei et al. (1999), although the ages of local granites reported by these authors are younger than the new ages and do not overlap with them within error. The Razi granites, which were syntectonic with movement on the NLTZ (Mkweli et al., 1995), were probably derived by remelting of the charnoenderbite suite (Berger et al., 1995).

The late Archaean deformation event, and intrusion of the Razi granites, was in turn followed by movement on the low-grade shears. The low-grade shear zones cannot have accommodated significant movement in themselves, because they are widely separated and of limited strike length. The maximum age of the shears is given by the youngest age of the porphyritic granites $(\sim 2580 \mathrm{Ma})$ that are cut by the medium grade shears that, in turn, predate the low grade shears, and by the $\sim 2533$ Ma age of the pegmatite, also deformed by this deformation event. The $2517 \pm 55 \mathrm{Ma}$ age of the porphyritic granite mentioned above (Frei et al., 1999) is a maximum age for this deformation, since this granite was affected by the medium grade deformation (Figure 12). Thus, the maximum age of the low-grade shear zones is latest Archaean. The minimum age of these shear zones is given by the age of the Nyamawanga dyke, which is $\sim 2.0 \mathrm{Ga}$ (see below).

On the basis of the similarity between the low grade shear zones and the titanite-bearing shear zones described by Kamber et al. (1996) from the Chiredzi River, it is likely that they are Palaeoproterozoic $(\sim 2.0 \mathrm{Ga})$ in age. The latest stages of this deformation 
may have involved pseudotachylite generation. The abundant chlorite that existed in these zones before pseudotachylite formation suggests that a hydrous fluid was present; however, according to some views of pseudotachylite generation, anhydrous conditions are a prerequisite (e.g. Mase and Smith 1985, Passchier and Trouw 1996). Magloughlin (1989) has argued that pseudotachylites can form in hydrous cataclasite, which is supported by the present observations.

The low-grade deformation was followed by intrusion of the Nyamawanga dyke. The northnorthwestern trend of the dyke is parallel to the Bubi swarm of dolerite dykes that intrudes the NMZ and basement rocks of the Zimbabwe craton (Robertson, 1973) and is parallel to the Sebanga Poort Dykes in the Zimbabwe Craton (Wilson, 1990; Wilson et al., 1987). Jones et al. (1975) used palaeomagnetic evidence to suggest that these dykes were emplaced coevally with the Mashonaland dolerites in the craton at $\sim 2.0 \mathrm{Ga}$. The age of the dolerite sills is only constrained by their lack of deformation: their petrographic similarities to the Nyamawanga dyke suggest a similar age.

The kinematics of the low grade shears are enigmatic. Kolb et al. (2002) have found evidence for a low-temperature (at or below $300^{\circ} \mathrm{C}$ ), normal shear sense deformation on shears at Renco Mine from quartz c-axis fabrics: they attributed this to Palaeoproterozoic deformation. The presence of pseudotachylites parallel to these shears (Kisters, personal communication) raises the possibility that the low grade shears of this study are part of this event.

\section{Implications for granulite formation and exbumation}

The apparent lack of regional displacement on the low grade shears implies that granulite facies exhumation occurred entirely during or earlier than the medium grade deformation in the latest Archaean. This is compatible with the lack of deformation of the Great Dyke in the NMZ (Blenkinsop and Mkweli, 1995), indicating that exhumation occurred there before $2575 \pm$ $0.7 \mathrm{Ma}$, the best age for the intrusion of the Great Dyke (Oberthür et al., 2002).

Single vs. two stage exhumation of the NMZ granulites is integral to the question of the thickness of the Archaean crust in the Limpopo region. In the twostage exhumation hypothesis of Kamber and Biino (1995) and Kamber et al. (1996), the crust was never thickened beyond $45 \mathrm{~km}$. However, the rationale for such a limited thickness of Archaean crust is partly based on the existence of later ("stage 4") exhumation, which is not compatible with the evidence presented above. Other reasons given by Kamber et al. (1996) for a limited Archaean crustal thickness are hypothetical: these are contributions to pressure from magmatic loading and deviatoric stress. Kramers et al. (2001) argued that the late Archaean igneous activity was more likely to be associated with an increase in basal heat flux than crustal thickening because the $\mathrm{Nd}$ isotope data suggests a component of mantle melt. The presence of some mantle melt does not necessarily preclude a thicker crust, however.

Two-stage exhumation is also inappropriate to the NMZ granulites because of the preservation of prograde textures in the granulites: these should not be recorded in granulites that have undergone cooling at depth (Ellis, 1987). Nor can it be argued that the NMZ granulites underwent two-stage exhumation because they were lower plate granulites: the NMZ is clearly in the hangingwall of the NLTZ, and the majority of it is in the hangingwalls of the medium grade shears (Figure 2).

Maximum pressures of $0.9 \mathrm{GPa}$ in the NMZ were calculated from orthopyroxene-garnet thermobarometry for the NMZ by Rollinson (1989), and a similar maximum of $0.8 \mathrm{GPa}$ was calculated from mafic granulites by Kamber and Biino (1995). These translate to crustal thicknesses of approximately $30 \mathrm{~km}$. Recent seismically derived estimates for the present crustal thickness in the NMZ give values of $37 \mathrm{~km}$, similar to values for the adjacent Zimbabwe craton (Nguuri et al., 2000), although the results are difficult to interpret and vary across the Limpopo Belt. The value of $37 \mathrm{~km}$ is the appropriate local figure and it is less than the thickness in other areas. Since granulite exhumation occurred in the Archaean, an extreme estimate of the thickness of the Archaean crust can be made as approximately $37 \mathrm{~km}$ $+30 \mathrm{~km}=67 \mathrm{~km}$. However, this would require a very unusual crustal thermal structure, in view of the high temperatures that the rocks at surface today reached in the Archaean; these have migmatitic segregations (Figure 4b). Although the thickness of the Archaean crust is not known, the constraints are compatible with a substantially thickened crust, sufficient to allow exhumation of the upper plate, NMZ granulite facies rocks in a single orogenic cycle. Estimates of the history of crustal thickness in the NMZ are further complicated because some crustal thinning may have occurred during the Karoo igneous event (Gwavava et al., 1992) and changes could also have occurred during the Palaeoproterozoic tectonism.

One implication of Archaean exhumation is that large amounts of sediments could have been produced by erosion of uplift that may have accompanied exhumation. Late Archaean cratonic cover sediments are common in several Archaean cratons, and indicate that uplift took place within a few hundred $\mathrm{Ma}$ of late Archaean tectonism, in accordance with observed and calculated exhumation rates (e.g. examples in Ellis, 1987; England and Thompson, 1984). The late Archaean Shamvaian metasediments and metavolcanics of the Zimbabwe craton are one possible record of such events in the Limpopo belt. The best timing constraints available for the Shamvaian are $2672 \pm 21$ Ma for a synvolcanic porphyry from the Shamva greenstone belt (Jelsma et al., 1996) and a similar age of $2661 \pm 17 \mathrm{Ma}$ for an upper Shamvaian felsite in a vent breccia in the Masvingo greenstone belt (Wilson et al., 1995). The minimum age of the Shamvaian is given by the age of 
the Great Dyke (2575 $\pm 0.7 \mathrm{Ma}$, Oberthür et al., 2002), which intrudes Shamvaian metasediments. These dates admit the possibility that the Shamvaian deposition occurred as response to erosion of the NMZ.

Dirks et al. (1997) proposed a model for granulite exhumation that could be considered for the NMZ granulites. In this model, uplift and downwelling of rocks occurs entirely within the crust itself as opposed to vertical movements on large structures between crustal blocks. Such uplift and downwelling has also been suggested for the Limpopo Belt by Gerya et al. (2000) and Perchuk et al. (2000). The preservation of both prograde and retrograde textures is a logical aspect of this model. The low viscosities/high temperatures implied by the model are a feature of the Kramers et al. (2001) heat flow model for the NMZ. However, one critical element that is missing in the NMZ is domains with dominantly sub-horizontal foliations, which form due to vertical shortening during uplift and doming. Pervasive foliation in the study area and the NMZ generally (e.g. Rollinson and Blenkinsop 1995) dips steeply. If the concept of intracrustal advection or convection applies to the NMZ, then the Dirks et al. (1997) model must be modified substantially to account for the observed structures.

\section{Implications for Mineralization}

The only (probable) Proterozoic structures identified in the area around Renco during this study are the narrow, short, low-grade shear zones that bear no signs of gold mineralization and have a distinctive development of chlorite. There is also evidence for low-grade deformation at Renco Mine, where there is agreement that it postdates ore formation (Blenkinsop and Frei, 1997; Kisters et al., 1997). Blenkinsop and Frei (op. cit.) argue that the close association between low grade deformation and mineralization supports a Palaeoproterozoic age for the latter, but Kisters et al. (1997; 1998; 2000) and Kolb et al. (2000; 2003) maintain that the low grade deformation is later and unconnected with the mineralization, that occurred at higher grade.

Both groups of authors agree that mineralization is associated with a biotite-pyrrhotite alteration assemblage, that on the one hand yields an age of $\sim 1.88$ $\mathrm{Ga}$ (from $\mathrm{Rb}-\mathrm{Sr}$ on the biotite), but on the other yields temperatures of more than $600^{\circ} \mathrm{C}$ from geothermometry (Kempen et al., 1997; Kisters et al., 1998). The results reported here indicate that if the mineralization is hightemperature, then it is not Proterozoic in age. Furthermore, if the mineralization is associated with the intrusion of pegmatites (Kisters et al., 1998), then the intrusive ages reported in this study confirm that mineralization must be Archaean.

The apparently contradictory evidence about the mineralization can be resolved if there was both an Archaean granulite-amphibolite facies event, and a Palaeoproterozoic, greenschist-facies event, as suggested by Blenkinsop and Frei (1997). The results of this study support this scenario because they document high-grade Archaean tectonism and a distinct, low-grade later event in the area around Renco Mine. This study qualifies the nature of the Palaeoproterozoic event: not only was it greenschist facies, but it involved negligible displacement on a crustal scale.

Regardless of the arguments about the timing of mineralization at Renco Mine, there are two important lessons to be drawn from field mapping around the mine. First, in view of the reactivation of Archaean fabrics during the Palaeoproterozoic event with the same sense of shear and shear direction as the earlier event, kinematic arguments cannot be used to constrain the age of the mineralizing event. Syn-mineralization thrusting to the north-northwest could have occurred in either the late Archaean or Palaeoproterozoic. Second, the field mapping suggests that the mineralization at Renco Mine does not continue in individual structures that are at an appreciably larger scale than the mine area itself. The restriction of gold mineralization to structures on the order of hundreds of metres in size rather than kilometres is a feature recognized in several high goldgrade deposits (e.g. Vearncombe, 1998; Blenkinsop et al., 2000). This clearly has implications for exploration, which should not focus exclusively on major regional-scale structures, and needs to provide an inventory of structures at a very detailed scale.

\section{Conclusions}

Mafic igneous and metasedimentary rocks in the NMZ were extensively intruded by charnoenderbites in the late Archaean from $\sim 2739$ Ma to $\sim 2571$ Ma, approximately coeval with peak granulite facies metamorphism ( 2720 to $\sim 2590 \mathrm{Ma})$. Crustal shortening and thickening was accompanied by thrusting of the NMZ over the Zimbabwe craton. Granites intruded over a similar period in the Renco area ( 2654 to $\sim 2517 \mathrm{Ma})$. Crustal thickening may have been sufficient to allow exhumation of the granulites during the same orogenic cycle in which they were formed in the late Archaean. The last phases of the intrusive event were porphyritic granites that intruded syntectonically, mainly along the thrust boundary between the NMZ and the craton, broadly diachronously from west to east.

The major tectonic event was followed by low grade deformation restricted to distinctive chlorite-rich shear zones of maximum strike length of a few hundred metres, separated by several kilometres along and across strike. The maximum age of this deformation is latest Archaean: it is likely that the low grade shear zones represent Palaeoproterozoic tectonism, a distal vestige of the granulite facies event that occurred along the Triangle Shear Zone and in the Central Zone (Kamber et al., 1995a; b; Holzer et al., 1998; Jaeckel et al., 1999). There was no intrusive activity associated with this event, which did not exhume the granulites. The latest stages of the event may have involved seismogenic faulting and pseudotachylite generation.

The enigma of the contradictory evidence for the age of mineralization at Renco Mine can be resolved within 
the context of the tectonic history deduced here for the local area. An initial Archaean mineralization satisfies constraints that demand a high grade for this event, while remobilization may have occurred during the Palaeoproterozoic to explain the association of the mineralization with biotite of this age.

\section{Acknowledgments}

We are grateful to Mike Rubenach for useful comments on an early version of this manuscript. A.K. acknowledges mass spectrometer analytical facilities in the Max-Planck-Institut für Chemie in Mainz. This research was supported by Rio Tinto Zimbabwe and by COMTEC, the Commission on Tectonics of (IUGS). Detailed reviews by Jan Kramers and Maarten de Wit helped to improve the paper.

\section{References}

Barton J.M., Jr and Van Reenen, D.D. (1992). When was the Limpopo Orogeny? Precambrian Research, 55, 7-16.

Barton, J.M., Holzer, L., Kamber, B., Doig, R., Kramers, J.D. and Nyfeler, D. (1994). Discrete metamorphic events in the Limpopo belt, southern Africa: implications for the application of $\mathrm{P}-\mathrm{T}$ paths in complex metamorphic terrains. Geology, 22, 1035-1038.

Berger, M. and Rollinson, H.R. (1997). Isotopic and geochemical evidence for extensive intracrustal mixing and homogenization during the Archaean. Geochimicha et Cosmochimica Acta, 61, 4809-4829.

Berger, M., Kramers, J.D. and Naegler, Th.F. (1995). Geochemistry and geochronology of charno-enderbites in the NMZ of the Limpopo Belt, Southern Africa, and genetic models. Schweizerische Mineralogische und Petrographische Mitteilungen, 75, 17-42

Blenkinsop, T.G. and Mkweli, S. (1995).The North Limpopo Thrust Zone Constraints on the exhumation of Archaean granulites in the Northern Marginal Zone, Limpopo Belt, Zimbabwe. Abstract, Tectonic Studies Group Annual General Meeting, Cardiff. U.K., 22 pp.

Blenkinsop, T.G., Mkweli, S., Rollinson, H.R., Fedo, C.M., Paya, B.K., Kamber, B., Kramers, J.D. and Berger, M., (1995). The North Limpopo Thrust Zone (NLTZ): The northern Boundary of the Limpopo belt in Zimbabwe and Botswana. Centennial Geocongress, Extended Abstracts, Geological Society of South Africa, 1, 174-177.

Blenkinsop, T.G. and Frei, R. (1996). Archaean and Proterozoic mineralization and Tectonics at the Renco Mine (NMZ, Limpopo Belt), Zimbabwe. Economic Geology, 91, 1225-1238

Blenkinsop, T.G. and Frei, R. (1997). Archaean and Proterozoic mineralization and Tectonics at the Renco Mine (NMZ, Limpopo Belt) Zimbabwe - Reply to discussion. Economic Geology, 92, 746-747.

Blenkinsop, T.G., Oberthür, T. and Mapeto, O. (2000). Gold mineralization in the Mazowe area, Harare-Bindura-Shamva greenstone belt, Zimbabwe: I. Tectonic controls on mineralization. Mineralium Deposita, Special Issue Current Ore Deposit Research in Germany, 35, 126-137.

Brandl, G. and Reimold, W.U. (1990). The structural setting and deformation associated with pseudotachylite occurrences in the Palala Shear Belt and Sand River Gneiss, Northern Transvaal. Tectonophysics, 171, 210-220.

Camacho, A., Vernon, R. H. and Fitz Gerald, J. D. (1995). Large volumes of anhydrous pseudotachylite in the Woodroffe Thrust, eastern Musgraves Ranges, Australia. Journal of Structural Geology, 17, 371-383.

Cocherie, A., Guerrot, C. and Rossi, P. (1992). Single-zircon dating by stepwise $\mathrm{Pb}$ evaporation: Comparison with other geochronological techniques applied to the Hercynian granites of Corsica, France. Chemical Geology, 101, 131-141.

Cox, K.G., Johnson R.L., Monkman, L.J., Stillman, C.J., Vail, J.R. and Wood, D.N. (1965). The geology of the Nuanetsi igneous province: Philosophical Transactions of the Royal Society of London, A 257, 71-218.

Dirks, P.H.G.M., Zhang, J.S. and Passchier, C.W. (1997). Exhumation of highP Granulites and the role of lower crustal advection in the North China Craton near Datong. Journal of Structural Geology, 19, 1343-1358.

Ellis, D.J. (1987). Origin and evolution of granulites in normal and thickened crusts. Geology, 15, 167-170

England, P. and Thompson, A. B. (1984). Pressure-temperature-time paths of regional metamorphism; I. Heat transfer during the evolution of regions of thickened continental crust. Journal of Petrology, 25, 894-928.

Frei, R. Blenkinsop, T.G., and Schonberg, R. (1999). Geochronology of the late Archaean Razi and Chilimanzi Suites of granites in Zimbabwe; implications for the late Archaean, tectonics of the Limpopo Belt and Zimbabwe Craton. South African Journal of Geology, 102, 55-63.

Gerya T.V., Perchuk L.L., van Reenen D. D. and Smit C. A. (2000). Twodimensional numerical modeling of pressure-temperature-time paths for the exhumation of some granulite facies terrains in the Precambrian. Journal of Geodynamics, 30, 17-35.

Grocott, J. (1981). Fracture geometry of pseudotachylite generation zones: a study of shear fractures formed during seisimic events. Journal of Structural Geology, 3, 169-179.

Gwavava, O., Swain, C.J., Podmore, F. and Fairhead, J.D. (1992). Evidence of crustal thinning beneath the Limpopo Belt and Lebombo monocline of southern Africa based on regional gravity studies and implications for the reconstruction of Gondwana. Tectonophysics, 212, 1-20.

Holzer, L., Kamber, B.S., Kramers, J.D. and Frei, R. (1996). The tectonometamorphic event at $2 \mathrm{Ga}$ in the Limpopo Belt and the resetting behaviour of chronometers at high temperature. Special Publication of the Geological Survey of Namibia, 1, 127-138.

Holzer, L., Frei, R., Barton, J.M. Jr. and Kramers, J.D. (1998). Unravelling the record of successive high grade events in the $\mathrm{CZ}$ of the Limpopo Belt using $\mathrm{Pb}$ single phase dating of metamorphic minerals. Precambrian Research, 87, $87-115$.

Holzer, L., Barton, J.M., Paya, B.K., and Kramers, J.D. (1999). Tectonothermal history in the western part of the Limpopo Belt: Test of tectonic models and new perspectives. Journal of African Earth Science, 28, 383-402.

Jaeckel, P., Kroner, A., Kamo, S.L., Brandl, G., and Wendt, J.L. (1997). Late Archaean to early Proterozoic granitoid magmatism and high-grade metamorphism in the central Limpopo belt, South Africa. Journal of the Geological Society, V 154, 25-44.

James, P.R. 1975. A deformation study across the northern margin of the Limpopo Mobile belt, Rhodesia. Ph.D. Thesis. University of Leeds, U.K., $369 \mathrm{pp}$

Jelsma, H.A., Vinyu, M.L., Valbracht, P.J., Davies, G.R., Wijbrans, J.R., and Verdurmen, E.D.A.T. (1996). Constraints on Archaean crustal evolution of the Zimbabwe craton: $\mathrm{A}$ U-Pb zircon, $\mathrm{Sm}-\mathrm{Nd}$ and $\mathrm{Pb}-\mathrm{Pb}$ whole rock isotope study. Contribution to Mineralogy and Petrology, 124, 55-70.

Jones, D., Robertson, I.D.M., and McFadden, P.L. (1975). A paleomagnetic study of Precambrian dyke swarms associated with the Great Dyke of Rhodesia. Transactions of the Geological Society of South Africa, 77, 339-345.

Kamber, B., Blenkinsop, T.G., Rollinson, H.R., Kramers, J.D. and Berger, M., (1992). Dating of an important tectono-metamorphic event in the NMZ of the Limpopo Belt, Zimbabwe: first results. North Limpopo Field Workshop Guide and Abstracts Volume, Geological Society of Zimbabwe, 39.

Kamber, B.S. and Biino, G.G. (1995). The evolution of high T - low P granulites in the NMZ sensu stricto, Limpopo Belt, Zimbabwe - the case for petrography. Schweizerische Mineralogische Petrographische Mitteilungen, 75, 427-454.

Kamber, B.S., Kramers, J.D., Napier, R., Cliff, R.A., and Rollinson, H.R. (1995a).The Triangle Shear zone, Zimbabwe, revisited: new data document an important event at $2.0 \mathrm{Ga}$ in the Limpopo Belt. Precambrian Research, 70, 191-213.

Kamber, B.S., Blenkinsop, T.G., Villa, I.M., and Dahl, P.S. (1995b). Proterozoic transpressive deformation in the NMZ, Limpopo Belt, Zimbabwe. Journal of Geology, 103, 493-508.

Kamber, B.S., Wijbrans, J.R., Biino, G.G., Villa, I.M., and Davies, G. (1996). Archaean granulites of the Limpopo Belt, Zimbabwe: one slow exhumation or two rapid events? Tectonics, 15, 1414-1430.

Kempen, T., Kisters, A.F.M., Glodny, J., Meyer, F.M., and Kramm, U. (1997). Lode gold mineralization under high grade metamorphic conditions: The Renco gold mine, Southern Zimbabwe (abstract.). Terra Nova, 9, 1, 549. Kisters, A. F. M., Kolb, J., and Meyer, F. M. (1997). Archeaen and Proterozoic mineralization and tectonics at Renco mine (Northern Marginal Zone), Limpopo Belt, Zimbabwe. A Discussion. Economic Geology, 92, 745-746. Kisters, A. F. M., Kolb, J., and Meyer, F. M. (1998). Gold mineralization in high grade metamorphic shear zones of the Renco mine, Southern 
Zimbabwe. Economic Geology, 93, 587-601

Kisters, A. F. M., Kolb, J., Meyer, F. M., and Hoernes, S. (2000). Hydrologic segmentation of high temperature shear zones: structural, geochemical and isotopic evidences from auriferous mylonites of the Renco mine, Zimbabwe. Journal of Structural Geology, 22, 811-829.

Kober, B. (1986). Whole-grain evaporation for ${ }^{207} \mathrm{~Pb} /{ }^{206} \mathrm{~Pb}$ investigation on single zircons using a double-filament thermal ion source. Contributions to Mineralogy and Petrology, 93, 482-490.

Kober, B. (1987). Single-zircon evaporation combined with $\mathrm{Pb}+$ emitterbedding for ${ }^{207} \mathrm{~Pb} /{ }^{206} \mathrm{~Pb}$-age investigations using thermal ion mass spectrometry, and implications to zirconology. Contributions to Mineralogy and Petrology, 96, 63-71.

Kolb, J., Kisters, A. F. M., Hoernes, S., and Meyer, F. M. (2000). The origin of fluids and nature of fluid-rock interaction in mid crustal auriferous mylonites of the Renco mine, Southern Zimbabwe. Mineralium Deposita 35, 109-125.

Kolb, J., Kisters, A. F. M., S., Meyer, F. M., and Siemes, H. (2003). Polyphase deformation of mylonites from the Renco gold mine (Zimbabwe) identified by crystallographic preferred orientation of quartz. Journal of Structural Geology, 25, 253-262.

Kramers, J.D., Kreissig, K., and Jones, M.Q.W. (2001). Crustal heat porductionproduction and satyle of metamorphprhism: a comparison between two Archeaen high grade provinces in the Limpopo Bellet, Southern Africa. precambrianPrecambrian Research, 112, 149-163.

Kröner, A., Byerly, C.R. and Lowe, D.R. (1991). Chronology of early Archaean granite-greenstone evolution in the Barberton Mountain Land South Africa, based on precise dating by single zircon evaporation. Earth and Planetary Science Letters, 103, 41-54.

Kröner, A., Jaeckel, P., and Williams, I.S. (1994). Pb-loss patterns in zircons from a high-grade metamorphic terrain as revealed by different dating methods: $\mathrm{U}-\mathrm{Pb}$ and $\mathrm{Pb}-\mathrm{Pb}$ ages for igneous and metamorphic zircons from northern Sri Lanka. Precambrian Research, 66, 151-181.

Kröner, A. and Hegner, E. (1998). Geochemistry, single zircon ages and Sm-Nd systematics of granitoid rocks from the Góry Sowie (Owl) Mts., Polish West Sudetes: evidence for early Palaeozoic arc-related plutonism. Journal of the Geological Society, 155, 711-724.

Kröner, A., Jaeckel, P, Hofmann, A, Nemchin, A.A. and Brandl, G. (1998) Field relationships and age of supracrustal Beitbridge Complex and associated granitoid gneisses in the Central Zone of the Limpopo Belt, South Africa. South African Journal of Geology, 101, 210-213.

Kröner, A., Jaeckel, P., Brandl, G., Nemchin, A.A., and Pidgeon, R.T. (1999) Single zircon ages for granitoid gneisses in the $\mathrm{CZ}$ of the Limpopo belt, southern Africa, and geodynamic significance. Precambrian Research, 93, 299-337.

Maddock, R. H. (1992). Effects of lithology, cataclasis and melting on the composition of fault-generated pseudotachylytes in Lewisan gneiss, Scotland. Tectonophysics, 204, 261-268.

Magloughlin, J. F. (1989). The nature and significance of pseudotachylite from the Nason terrane, North Cascade Mountains, Washington. Journal of Structural Geology, 11, 907-917.

Mase, C. W. and Smith, L. (1985). Pore fluid pressure and frictional heating on a fault surface. Pure and Applied Geophysics, 122, 583-607.

McCourt, S. and Vearncombe, J.R. (1987). Shear zones bounding the CZ of the Limpopo Mobile belt. Journal of Structural Geology, 9, 127-137.

McCourt, S. and Vearncombe, J.R. (1992). Shear zones of the Limpopo belt and adjacent granitoid-greenstone terranes: implications for late Archeaen collision tectonics in southern Africa. Precambrian Research 55, 553-570.

Mkweli, S., Kamber, B. and Berger, M., 1995, A westward continuation of the Zimbabwe craton-NMZ tectonic break and new age constraints on the timing of the thrusting. Journal of the Geological Society of London, 152, 77-83.

Mkweli, S. (1998). The Zimbabwe Craton-Northern Marginal Zone boundary and the exhumations process of lower crustal rocks. Unpublished D. Phil thesis, University of Zimbabwe.186 pp

Nguuri, T. K., Gore, J., James, D.E., Webb, S.J., Wright, C., Zengeni, T. G., Gwavava, O. and Snoke, J. A. (2001). Crustal structure beneath southern
Africa and its implications for the formation and evolution of the Kaapvaal and Zimbabwe cratons. Geophysical Research Letters, 28, 2501-2504.

Oberthür, T, Davis, D.W., Blenkinsop, T.G. and Höhndorf, A, A. (2002). A Precise U-Pb mineral ages, Rb-Sr and $\mathrm{Sm}-\mathrm{Nd}$ systematics for the Great Dyke, Zimbabwe - constraints on crustal evolution and metallogenesis of the Zimbabwe Craton. Precambrian Research, 113, 293-305.

Passchier, C. W. and Trouw, R. A. J. (1996). Microtectonics. Springer-Verlag, Berlin Heidelberg New York, 289pp.

Perchuk L.L., Gerya T.V., Van Reenen D.D., Smit C.A, Krotov A.V., Safonov O.G. and Shur M.Yu. (2000). Comparable petrology and metamorphic evolution of the Limpopo (South Africa) and Lapland (Fennoscandia) highgrade terrains. Mineralogy and Petrology, 69, 69-107.

Ridley, J. (1992). On the origins and tectonic significance of the Charnockite suite of the Archaean Limpopo Belt, NMZ, Zimbabwe. Precambrian Research, 55, 407-427.

Robertson, I.D.M., (1973). The geology of the country around Mount Towla, Gwanda District. Rhodesia Geological Survey Bulletin, 68

Rollinson, H.R. (1989). Garnet-orthopyroxene thermobarometry of granulites from the north marginal zone of the Limpopo belt, Zimbabwe. In: J. S. Daly, R.A. Cliff and B.W.D. Yardley, (Editors). Evolution of metamorphic Belts: Geological Society Special Publication, 43, 331-335.

Rollinson, H.R. and Lowry, D.L. (1992). Early basic magmatism in the evolution of the North marginal zone of the Archaean Limpopo belt. Precambrian Research, 55, 33-45.

Rollinson, H.R. (1993). A terrane interpretation of the Archaean Limpopo Belt. Geological Magazine, 130, 755-765.

Rollinson, H.R. and Blenkinsop, T.G. (1995). The magmatic, metamorphic and tectonic evolution of the Northern Marginal Zone of the Limpopo Belt in Zimbabwe. Journal of the Geological Society of London, 152, 65-77.

Schaller, M., Steiner, O., Studer, I., Holzer, L., Herwegh, M. and Kramers, J.D. (1999). Exhumation of Limpopo Central Zone granulites and dextral continent-scale transcurrent movement at $2.0 \mathrm{Ga}$ along the Palala shear zone, Northern Province, South Africa. Precambrian Research, 96, 263-288.

Spray, J. G. (1995). Pseudotachylite controversy: Fact or friction? Geology, 23, 1119-1122.

Streckeisen, A.L. (1976). Classification of the common igneous rocks by means of their chemical composition: a provisional attempt. Neues Jabrbuch für Mineralogie, Monatshefte, H. 1, 1-15.

Tsunogae, T., Miyano, T. and Ridley, J. (1992). Metamorphic P-T profiles from the Zimbabwe Craton to the Limpopo Belt, Zimbabwe. Precambrian Research, 55, 259-278.

Van Biljon, W.J., and Legg, J.H. (Editors), (1983). The Limpopo Belt. Special Publication of the Geological Society of South Africa, 8, 203pp.

Van Breemen, O. and Hawkesworth, C.J. (1980). Sm-Nd isotopic study of garnets and their metamorphic host rocks. Transactions of the Royal Society of Edinburgh: Earth Sciences, 71, 97-102.

Van Reenen, D.D., Roering, C., Ashwal, L.D. and De Wit, M.J. (Editors), (1992). The Archaean Limpopo granulite belt: Tectonics and deep crustal processes. Precambrian Research, 55, 587pp.

Vearncombe, J.R. (1998). Shear zones, fault networks and Archaean gold. Geology 26, 769-864

Wilson J.F., Jones D.L. and Kramers J.D. (1987). Mafic Dyke swarms in Zimbabwe: In: H.C. Halls and W.F. Fahrig (Editors), Mafic Dykes Swarms, Geological Society of Canada Special Paper 33, 433-444.

Wilson, J.F. (1990). A craton and its cracks: some of the behaviour of the Zimbabwe block from the late Archaean to the Mesozoic in response to horizontal movements, and the significance of some of its mafic dyke fracture patterns. Journal of African Earth Sciences, 10, 483-501.

Wilson, J.F., Nesbitt, R.W. and Fanning, C.M. (1995). Zircon geochronology of Archaean felsic sequences in the Zimbabwe Craton: a revision of greenstone stratigraphy and a model for crustal growth. In: M.P. Coward and A.C. Ries, (Editors), Early Precambrian Processes. Geological Society of London Special Publication, 95, 109-126.

Editorial handling: J. M. Barton 